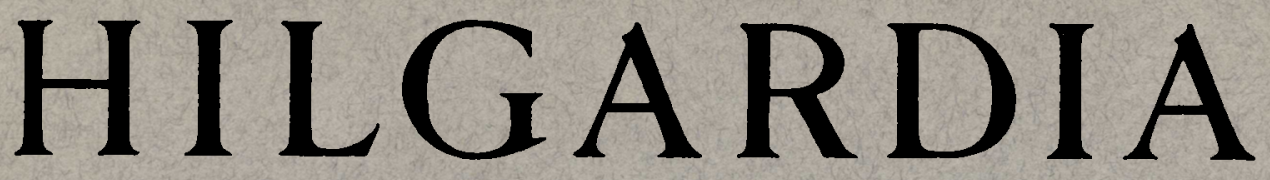

A Journal of Agricultural Science Published by the California Agricultural Experiment Station

\title{
RELATIVE GROWTH AND HEREDITARY SIZE LIMITATION IN THE DOMESTIC FOWL
}

\author{
I. MICHAEL LERNER
}




\section{$\begin{array}{lllllllll}H & \text { I } & \text { L } & G & \text { A } & \text { R } & \text { D } & \text { I } & \text { A }\end{array}$}

A Journal of Agricultural Science Published by

the California Agricultural Experiment Station

VoL. 10

FEBRUARY, 1937

No. 13

\section{RELATIVE GROWTH AND HEREDITARY SIZE LIMITATION IN THE DOMESTIC FOWL ${ }^{1}$}

\section{MICHAEL LERNER ${ }^{2}$}

THE PROBLEM OF SIZE INHERITANCE has been extensively studied by many investigators since Mendel's demonstration of a genetic basis for stature in peas. Many different types of study have been undertaken by different investigators, working with diverse material. Probably, however, no single method of investigation is capable of yielding a complete solution to a problem as complex as that of size inheritance, and any individual approach can only be considered as giving additional evidence on the subject. In order to evaluate the contribution of such single approach, the problem as a whole must be visualized. Hence, when an attempt is made to present new evidence from a little-explored approach, an inventory of the work that has been done in this general field may be timely.

\section{REVIEW OF LITERATURE}

In general, data obtained on various plants and animals show that the basis of size inheritance may in some cases be vested in single-factor differences and in other cases in a rather complicated scheme of multiple factors.

Cases of Single-Factor Control of Size Differences. - Cases of the first type are comparatively rare, although they extend throughout both the plant and the animal kingdom. In some instances it may be suspected that the single factors exert their influence at some critical stage of growth, affecting the development of certain organs which control size. Such, for instance, is the "dwarf" gene in mice, described by Snell (1929), which wás shown by Smith and MacDowell $(1930,1931)$ to affect the produc-

${ }^{1}$ Received for publication August 19, 1936.

2 Instructor in Poultry Husbandry.

"See "Literature Cited" at the end of this paper for complete data on citations, which are referred to in the text by author and date of publication. 
tion of the anterior pituitary growth hormone. Kemp (1933), who described the histology of the normal and "dwarf"'hypophyses, found differences in their development. The dwarf condition in rats, described by Lambert and Sciuchetti (1935), which was also found to be monofactorial in nature, may well be due to similar differences. Although hypophyseal implants in this case did not alleviate the dwarf condition, these workers suggest an endocrine basis for the reduction in size. The case of the dwarf fowl (Mayhew and Upp, 1932; Upp, 1934) has not found an explanation as yet though its inheritance on an autosomal monofactorial basis is indicated. Sollas $(1909,1914)$ reported an achondroplasialike dwarf character in the guinea pig, which was recessive in its inheritance, while Greene, Hu and Brown (1934) reported a lethal dwarf mutation in the rabbit.

In Drosophila single genes affecting size have been described, notably the "giant" of Bridges and Gabritschevsky (1928), while several cases have been recorded in plants (for example, Miyazawa, 1921; Stanton, 1923 ; Elders, 1928 ; Clarke, 1931 ; Sieglinger, 1933 ; Ramiah, 1933 ; Harland, 1934).

Cases of Multiple-Factor Control of Size Differences.-The second type of size inheritance, however, is one of particular interest. Sinnott and Dunn (1935) gave an excellent review of the literature and of the status of the problem to date. They list five lines of evidence for the multiple-factor control of quantitative characters in general and of size in particular. Before presenting these here, it may be noted that at least one worker (Castle, 1929, 1933b) has questioned the concept of chromosomal control of size factors. On the basis of the results of Moore (1933), who found maternal rates of cleavage in hybrids of lower marine forms, even when the zygotes were denucleated, Castle suggests the existence of a cytoplasmic control of size inheritance. The rejoinder of Dobzhansky (1934), who shows that the multiple-factor hypothesis fits best to most of the data on hand and the evidence obtained by Green (1930 et seq.), Feldman (1935), and Maw (1935), to be referred to later, disposes fairly well of Castle's objections to the theory of genic control of size. Yet as Marshak (1936) points out, growth rates may be the result of interaction of genes with cytoplasm; and because of the possibility of argument in this field, particular emphasis is laid on the evidence for the theory as outlined by Sinnott and Dunn. The five major lines of evidence pointing to the validity of the multifactorial concept are listed as follows :

1. The variability of the $\mathrm{F}_{2}$ generation is greater than that of the $\mathrm{F}_{1}$.

2. Genetical distinctness of the $\mathrm{F}_{3}$ progenies from various points on the $\mathrm{F}_{2}$ curve of distribution. 
3. Linkage of some genes for quantitative characters with those usually referred to as qualitative characters.

4. Evidence from Datura, that each chromosome may have a bearing on some quantitative trait.

5 . Occurrence of the phenomenon of heterosis.

Most of the above conditions have been observed in many different forms, although only in a very few cases have definite factorial bases for size differences been assigned. The work of Lock (1906) and Emerson and East (1913) on maize, of Keeble and Pellew (1910) and de Haan (1927) on peas, of Nillson-Ehle (1909), Freeman (1919), and Tingey (1932) on wheat, of Emerson (1910), Sax (1924) and Frets and Wanrooy $(1934,1935)$ on beans, and many others can be cited from the plant kingdom.

In some cases definite single factors have been discovered. Thus Frost (1923) found linkage of size genes with color genes in the radish. Lindstrom (1928) succeeded in isolating a major gene affecting fruit size in tomatoes, while Currence (1932) also located a size factor on a marked chromosome in the same species. Smith (1935) reported linkage of one of the factors affecting corolla size in tobacco with a color factor, and Weetman (1935) found association of rind marking with size of watermelons. A question of importance was raised in some of this work as to an additive or a multiplicative effect of size genes, with Crane and Lawrence (1933) and Lindstrom (1935) presenting evidence for the first. type of action, and Dale (1928) and Kaiser (1935) for the second.

Size-Inheritance Studies with Animals.-Very numerous too are the investigations with animals, most of which, however, were purely empirical types of study. Linear or mass measurements were classified phenotypically and in most cases blending inheritance was found to exist. In the larger animals, Spöttel (1932) described size inheritance in crosses of eattle with related forms, and Hammond (1920) worked on breed crosses in cattle. In swine Wellman (1913), Hammond (1922), Schmidt, Lauprecht, and Winzenburger (1934) presented evidence of the same general type. Hammond (1921), Ritzmann (1923), Davy (1927) and Spöttel (1932) worked with sheep. In laboratory mammals, Castle (1909 et seq.), MacDowell (1914), Punnett and Bailey (1918), Kopeć (1924), Pease (1928) and Robb (1929a) presented results of crosses between various breeds of rabbits; Castle (1916), also worked with guinea pigs as did Detlefsen (1914), while Livesay (1930) crossed different strains of the Norway rat. Vetulani (1930), Green (1930 et seq.) and Feldman (1935) gave evidence on size inheritance in mice. Here Green (1931 a) was able to demonstrate linkage of one of the size factors 
with a gene for a coat-color character, while Feldman also isolated a major gene for size. Castle, Gates, and Reed (1936) propose that the genes for some of the coat characters themselves have an effect on size. In man, Davenport $(1917,1924)$ made the most exhaustive study on the subject of inheritance of stature.

Domestic fowl were a popular material in this field with Ghigi (1909), Punnett and Bailey (1914), May (1925), Sokolov (1926), Ghigi and Taibell (1927), Kopeć (1927), May and Waters (1927), Kondyrev (1928), Danforth (1929), Warren (1930), Jull and Quinn (1931), Waters (1931, 1934), Lerner and Asmundson (1932), Axelsson (1933), Zorn and Krallinger (1934) and Lauth (1935), describing a variety of crosses from the standpoint of size inheritance. The same problem was studied in ducks by Phillips $(1912,1914)$ and by Goldschmidt (1913). A most important contribution was that of Maw (1935) who found one of the factors responsible for size differences between Sebright Bantams and Light Brahmas to be sex-linked. This work will be discussed in greater detail in a later section.

While variable results were obtained by the different workers, it became evident from the mass of data accumulated that further progress by these means in all probability would not lead to the complete solution of the problem. Several other approaches were tried and some of them yielded valuable leads.

Studies on the Morphological Basis for Size Differences.-Such, for instance, was the work designed to determine the morphological basis for size differences. Obviously individuals differing in total size must differ either in number or size of cells. Of the reports dealing with the subject in addition to the literature reviewed by Sinnott and Dunn (1935)which includes among others the work on rabbits of Painter (1928), Castle and Gregory (1929) and Gregory and Castle (1931) - the work of Keller (1933) on the fowl may be cited as showing that cell-number and not cell-size differences are responsible for differences in total size.

On the other hand, there is also work indicating that cell size may in some cases play a part. Rensch (1923) has given a thorough review of this subject, as have Sinnott and Dunn, citing a number of workers who found that in polyploid series body size was roughly proportional to cell size. Rensch, in contradiction to the later work of Keller (1933), found not only cell-number but also cell-size differences between large and small races of fowl, while Dobzhansky (1929) found that reduced wing size in "miniature" Drosophila was due, to smaller cells. Houghtaling (1935) concluded that fruit size in the tomato depends on both cell size and cell number, while Sinnott (1935b) states that in some cases, such 
as that of the watermelon, size differences are due to a great expansion of a relatively small number of cells, but in others, such as the mammoth pumpkin, to a lesser expansion of a greater number of cells.

From this and other evidence many of the workers have concluded that ultimate size of an organism is determined early in its development. Thus, Ford and Huxley (1927) state that defined adult absolute size was inherited and hence an interpretation follows that developmental processes are a function of this heritable character. In keeping with this, Castle and Gregory (1929) and Gregory and Castle (1931) observed differences in the rate of cell proliferation in rabbit embryos of races with different adult sizes. Blunn and Gregory (1935) confirmed this for chickens.

As far as some of the chemical factors involved are concerned, their expression may also be a function of the final weight. Thus Gregory and Goss (1933a et seq.) found differences in the glutathione concentration of small and large races of rabbits at the time of birth. Similar findings in the embryos of chickens are reported by Gregory, Goss, and Asmundson (1935).

Lerner and Asmundson (1932) and Asmundson and Lerner, (1933, 1934) attempted to find differences in the rate of growth leading to the difference in final size in fowls and established early differential rates of growth in various breeds. Of the other studies on the bases of size difference, the work of Kaufman (1927 et seq.) on pigeons and chickens, showing that the final size difference between these two species is due to an original size difference, and that of Byerly (1930) on chicken embryos must be mentioned, as well as the interpretation of the latter's work by Castle and Gregory (1931), who demonstrated that crossbred embryos grow faster than purebred ones.

Many of the papers cited are important contributions to the problem, yet the status of the question is far from satisfactory at this time. While the multiple-factor theory can probably satisfy the results obtained from most of the crosses, especially if allowance is made for factor interaction or if Rasmusson's (1933) indication that 100-200 genes should be considered as involved in the segregation of quantitative characters is accepted, the mode of action of these factors on the dynamies of size differentiation is not at all understood.

General and Special Size Factors.-A rather important question is whether or not size genes are general in their effect. A controversy on this subject took place between Castle (1914 et seq.) and Sumner (1923 1924), with the former taking the stand that factors for size are mostly general in their effect, while the latter assumed that there are factors 
affecting only the size of parts. The work of Davenport $(1917,1924)$ and of Mjoen (1923, 1926), reporting disharmonies in proportion found in human interracial crosses, was cited as supporting the latter point of view. The data of Eckles and Swett (1918) may be by inference interpreted to mean that factors affecting skeletal growth in cattle are common to all bones. Gregory (1933), also working with cattle, found that factors affecting linear development may be different from those affecting muscular development. Rumiantzev (1932), studying bone variability in rabbits, found a preponderance of general factors. Kopeć and Latyszewski (1930) give evidence for the existence of general factors in mice, while Green and Fekete (1933) and Green (1934) found both general and group factors in mouse crosses. Schkljar (1935) states that the growth of some organs in the chick embryo is "subject to general conformity to law."

The most illuminating of all is the work of Wright (1932) based on the extension of his original path coefficient analysis of general, group, and special factors (Wright, 1918). Using the data of Castle, he found that genetic differences in the size of rabbits were largely due to general factors and to a small extent to group and special factors. His analysis of the data of Dunn (1928) on the bones of inbred White Leghorn fowls revealed that here too general factors were predominant, but group and special factors were also of some importance.

In this problem special cases have to be distinguished from the general ones. Of frequent occurrence are the cases where genes affect only certain parts and organs, and these must be differentiated from the conditions prevalent in ordinary circumstances. Sinnott and Dunn (1935) list a number of these cases : brachydactyly ; Ancon sheep ; Creeper fowl ; tail length in fowl, mouse, cat; ear length in mouse, sheep; hair length in rabbit, guinea pig, cat; comb in fowl; wing size, eye size, leg length, bristle length in Drosophila; and many cases in plants.

To this list may be added the genes for size of parts in the dog: short legs (Plattner, 1911; Wellman, 1916 ; Stockard, 1932), short tail (Klodnitzky and Spett, 1925), short head (Wriedt, 1929). Other cases include rumplessness in the fowl (Dunn, 1925; Landauer, 1928); probably an achondroplasialike condition in cattle (Crew, 1923; Mohr, 1929); the amputated condition in cattle (Wriedt and Mohr, 1928); hypotrichosis in mice (Loeffler, 1934) and other animals; atrichosis in mice (Brooke, 1926 ; Lebedinsky and Dauvart, 1927; Snell, 1931) and rabbits (Kislovsky, 1928) ; and ectromelus (Rabaud, 1914; Cuénot, 1928) in mice. Another interesting case is that of factors for thyroid size in ring doves, described by Riddle (1929). 
In many of these cases it is obvious that while the manifestation of the gene involved is in only one organ or part, the effect is a general one. For instance, some of the genes when homozygous are found to be lethal. Such are the cases of brachyury and anury in mice (DobrovolskaiaZavadskaia and Kobozieff, 1930; Chesley, 1932, 1935 ; Ephrussi, 1933; Kobozieff, 1934), and the Creeper condition in the fowl (Landauer and Dunn, 1930). Reduced viability in short-tailed cats is reported by Schwangart and Grau (1931), and in short-tailed dogs by Klodnitzky and Spett (1925). Hunt, Mixter, and Permar (1933) showed that other effects are present in mice bearing the flexed-tail gene, and Kamenoff (1935) reported this condition to be the result of a general effect, associated with growth retardation and anemia.

The reason why such genes find their expression in certain parts of the body may be that their action takes place at what Stockard (1921) terms "critical moments" of growth for the parts concerned. Thus Kamenoff (1935) invokes this theory in explanation of the failure of cartilages to differentiate normally, resulting in the flexed tail with associated general effects in the mouse. This is also borne out by Danforth's (1932) production of rumpless fowls by fluctuations in incubator temperature at the probable time of most active differentiation of the posterior part. Of great importance is the contribution of Landauer (1934), who found that changes in the bones of Creeper fowls are secondary to a general growth retardation. This was confirmed by Fell and Landauer (1935) from studies of tissues in vitro.

The problem arises as to whether or not in normal individuals the differences in size of parts contributing to differences in total size are due to different genes or to the differential effect of the same genes on the rate of growth of these parts. The most advanced statistical method of studying the question of special factors, evolved by Wright (1932), does not answer this point. Robb (1935), from his study of equine skulls, claims that single-gene differences in size may produce a differential effect on the parts. In rats of the same size and presumably of a similar genetic constitution for total size, the rate of growth of some parts was found by Moment (1933) to be dependent on the body size, irrespective of age. It should be noted that these rats were kept under conditions promoting rapid or slow rate of total body growth at will. From this a suggestion may be made that general factors affect the growth of each part involved in this case in accordance with its respective growth capacity.

Investigation of the growth relation of parts in individuals differing in the pattern of growth of various organs may throw additional light on the problem. The application of the concept of heterogony, which is to 
be discussed in fuller detail below, has not been utilized to any great extent in studies of hereditary size limitation. The work that has been conducted from this angle will be referred to in the discussion of results presented.

The present investigation was started with the object of analyzing the genetic control of the growth of parts in relation to the growth of the whole body. Of the three phases of growth, chemo-, histo-, and auxanodifferentiation (Huxley, 1932) the last-named was considered to be most suitable for the application of available statistical methods because during it only quantitative growth changes in size and proportions may take place.

\section{CHOICE OF MATERIAL}

Advantages of the Domestic Fowl.-In studies of inheritance of quantitative characters in larger animals, the domestic fowl (Gallus gallus domesticus) forms particularly favorable material. This is largely because control of certain environmental conditions is possible in this species. Thus a large number of siblings may be hatched on the same day and raised uniformly, without being subject to such limitations as small families or to environmental differences due to differences that occur in mammals, such as the number in a litter and the maternal state of nutrition. More comparable figures on various aspects of growth can be obtained by standardizing the feeding and other environmental factors.

From the standpoint of studying parts, the domestic fowl is probably on a par with the laboratory mammals, since fairly extensive data are available on the post-hatching growth and relative size of organs and structures. The work of Latimer (1924, et seq.) particularly, as well as the data of Zaitschek (1908), Latimer and Pedersen (1923), Souba (1923), Mitchell, Card, and Hamilton (1926, 1931), Kach and Dyman (1934), and Hopkins and Biely (1935) may be cited as giving pertinent data on the subject.

Choice of Breeds.-In attempting the investigation of the genetic basis of the growth of parts in relation to the whole, two possible avenues of approach present themselves. The hybrids investigated may be (1) between breeds or strains of different size, or (2) between breeds of the same size but of varying proportions of parts. The first approach would introduce a variable in the form of total size and consequently may complicate the methods of investigation. The second method theoretically should provide a sounder basis for comparison of parts and for establishing any possible genetic differences in their relative growth, since the variable in the form of total body size would be in this case held constant. 
It was believed at the outset of this investigation that the Plymouth Rock and the Minorca breeds of the domestic fowl would answer specifications for material for the latter method of approach. In appearance the two breeds differ markedly, the first one being a fairly low-set, roundedout bird, while the second is high-set and somewhat angular in body shape. The standard weights of these breeds, as determined by the American Standard of Perfection (American Poultry Association, 1930) are as follows :

\begin{tabular}{|c|c|c|}
\hline & $\begin{array}{l}\text { Plymouth Rock } \\
\text { lbs. }\end{array}$ & $\begin{array}{l}\text { Minorca } \\
\quad \text { lbs. }\end{array}$ \\
\hline Cockerel & .. 8 & $71 / 2$ \\
\hline Cock & $91 / 2$ & 9 \\
\hline Pullet & 6 & $61 / 2$ \\
\hline Hen & $\ldots \ldots \quad 71 / 2$ & $71 / 2$ \\
\hline
\end{tabular}

These weights represent the ideal for exhibition and the objective of attainment by breeders of the two respective breeds of fowl. Although considerable variation exists within the breeds, it may be said that most of the well-established strains have characteristic weights, deviating only within reasonable limits from the standard, this deviation being usually in the direction of lower weights.

As far as the breeding behind the two varieties is concerned, evidence on hand indicates that they have no common ancestors since records have been kept (Brown, 1906; Robinson, 1924). The Minoreas were introduced from the Mediterranean into England about 1780 and appeared in the United States as an importation from that country in 1884 or 1885. The Plymouth Rock by that time had been exhibited for more than ten years, originating in America from crosses of English and Asiatic fowls.

While the total size of the two breeds is approximately the same, the assumption that differences exist in such factors as bone length and muscular development had, to judge from the external appearance of the birds, some basis. The selection of the particular structures to be studied was governed by various considerations, such as the possible significance of differences and the ease of dissection. The original outline of the experiment provided for preliminary studies on several organs and parts. After some work with the material, however, it was found impracticable to study most of the originally proposed structures, and the final choice fell on the pectoralis major and the long bones of the leg. The actual material used and the dissection technique employed is described in the next section. 


\section{MATERIAL AND METHODS}

Stock Used.-The original parental stocks used for this investigation came from three sources. Twelve yearling hens and 2 cockerels of known pedigree were purchased from a California breeding farm to form the foundation Barred Plymouth Rock stock. Four hens of the University of California flock and 6 hens and 2 cockerels obtained from a southern California breeder formed the Black Minorea foundation stock. These breeds were first mated in two pens in 1934, so as to give purebred and reciprocal cross progeny. These birds and some of their progeny were remated the following winter in six pens to produce additional purebreds and first crosses, as well as backcrosses to both of the parental breeds to the total number of ten matings. The pens were arranged in pairs and the males interchanged between the paired pens, so as to obtain samples representative of the population and not of individual families. All of the chicks were individually pedigreed.

Altogether nine hatches of chicks were used, four in the first and five in the second breeding season. These were raised under practically identical conditions at the University poultry plant. The only deviation from the standard brooding system was practiced in the first three hatches of the first year, which were kept in a battery brooder for the first five weeks of their life. The standard University of California mash was used and did not vary throughout the whole of the investigation. It consisted of the following ingredients :

\begin{tabular}{|c|c|c|}
\hline & Per cent & Per cent \\
\hline yellow co & 52.5 & Dehydrated alfalfa. \\
\hline Groun & 10.0 & Ground oystershell.... \\
\hline Wheat bra & 15.0 & Bonemeal ........ \\
\hline Fish $n$ & 9.5 & Salt ... \\
\hline Dried milk. & 5.0 & Cod-liver oil \\
\hline
\end{tabular}

Whole grain in the proportion of 2 parts corn to 1 part wheat was fed beginning at four weeks of age and gradually increasing in amount until, at sixteen weeks of age, half of the feed consumed consisted of the whole-grain mixture.

The birds were weighed at regular intervals, and observations were made on the color of plumage and the rate of tail-feather growth. These, however, were found to be of little value in analyzing the results, both being controlled by genes located on the sex chromosome, while no sexlinkage was found in the other data studied.

At various ages, groups of birds were killed and dissected in accordance with the technique described below. All of the birds surviving to the ages at which random selections for killings were made, with the 
exception of sick or otherwise abnormal individuals, were eventually used for that purpose. In all, seventeen dissection series were carried through.

Table 1 records the number of chicks used, arranged according to the age of the birds at the time the dissections were made. It also shows the

TABLE 1

Distribution of Birds Dissected by Mating, Sex, and Age

\begin{tabular}{|c|c|c|c|c|c|c|c|c|c|c|c|c|c|}
\hline \multirow{2}{*}{ Mating* } & \multirow{2}{*}{ Sex } & \multirow{2}{*}{$\begin{array}{l}\text { Group } \\
\text { No. }\end{array}$} & \multicolumn{10}{|c|}{ Age in Weeks } & \multirow{2}{*}{ Total } \\
\hline & & & 2 & 4 & 8 & 9 & 10 & 12 & 14 & 16 & 20 & $28+$ & \\
\hline \multirow{2}{*}{$\begin{array}{l}\text { Barred Plym- } \\
\text { outh Rock..... }\end{array}$} & $\int 0^{\pi}$ & 1 & 1 & 8 & 3 & 0 & 0 & 3 & 0 & 20 & 8 & 3 & 46 \\
\hline & \% & 2 & 1 & 11 & 2 & 0 & 1 & 3 & 1 & 10 & 3 & 10 & 42 \\
\hline \multirow{2}{*}{ Black Minorca } & $\int$ & 3 & 0 & 12 & 2 & 1 & 2 & 2 & 2 & 8 & 2 & 6 & 37 \\
\hline & 9 & 4 & 1 & 9 & 2 & 2 & 0 & 4 & 0 & 8 & 1 & 14 & 41 \\
\hline \multirow{2}{*}{$1 \times 4$} & $\int \sigma^{\pi}$ & .5 & 3 & 12 & 5 & 2 & 0 & 1 & 0 & 2 & 3 & 10 & 38 \\
\hline & \{ & 6 & 1 & 12 & 2 & 4 & 1 & 3 & 1 & 3 & 2 & 4 & 33 \\
\hline \multirow{2}{*}{$3 \times 2$. } & $\left\{0^{x}\right.$ & 7 & 7 & 22 & 1 & 6 & 8 & 5 & 4 & 13 & 1 & 19 & 86 \\
\hline & $\left\{\begin{array}{l}9 \\
9\end{array}\right.$ & 8 & 4 & 17 & 2 & 4 & 3 & 3 & 4 & 7 & 4 & 9 & 57 \\
\hline \multirow{2}{*}{$1 \times 6 \ldots \ldots \ldots$} & $\left\{\sigma^{7}\right.$ & 9 & 4 & 11 & 1 & 2 & 5 & 6 & 1 & 4 & 2 & 0 & 36 \\
\hline & $\{9$ & 10 & 5 & 8 & 4 & 5 & 1 & 6 & 3 & 1 & 3 & 0 & 36 \\
\hline \multirow{2}{*}{$1 \times 8}$. & $\left\{0^{x}\right.$ & 11 & 0 & 5 & 0 & 2 & 3 & 2 & 3 & 3 & 2 & 0 & 20 \\
\hline & 9 & 12 & 2 & 4 & 1 & 0 & 2 & 3 & 2 & 1 & 2 & 0 & 17 \\
\hline \multirow{2}{*}{$3 \times 6}$. & $\int \sigma^{7}$ & 13 & 3 & 12 & 3 & 2 & 6 & 3 & 5 & 2 & 0 & 0 & 36 \\
\hline & $\left\{\begin{array}{l}0 \\
0\end{array}\right.$ & 14 & 2 & 10 & 4 & 5 & 3 & 8 & 2 & 3 & 3 & 0 & 40 \\
\hline \multirow{2}{*}{$3 \times 8$} & $\int 0^{x}$ & 15 & 2 & 10 & 0 & 3 & 2 & 4 & 2 & 2 & 1 & 0 & 26 \\
\hline & $\{9$ & 16 & 3 & 9 & 2 & 3 & 2 & 2 & 3 & 4 & 0 & 0 & 28 \\
\hline \multirow[b]{2}{*}{$5 \times 2$} & $\int 0^{\pi}$ & 17 & 2 & 7 & 2 & 4 & 3 & 5 & 5 & 5 & 2 & 0 & 35 \\
\hline & $\left\{\begin{array}{l}0 \\
0\end{array}\right.$ & 18 & 0 & 11 & 3 & 2 & 4 & 4 & 3 & 4 & 5 & 0 & 36 \\
\hline \multirow{3}{*}{$7 \times 2$} & $\int \sigma^{x}$ & 19 & 2 & 11 & 4 & 4 & 1 & 7 & 4 & 3 & 3 & 0 & 39 \\
\hline & $\{0$ & 20 & 4 & 5 & 7 & 3 & 1 & 4 & 1 & 3 & 3 & 0 & 31 \\
\hline & & & - & - & - & - & - & - & - & - & - & - & $\overline{7 e n}$ \\
\hline Total. & .. & $\ldots$ & 47 & 206 & 50 & 54 & 48 & 78 & 46 & 106 & 50 & 75 & 760 \\
\hline
\end{tabular}

* The figures refer to the numbers of the groups used as parents for the various matings.

distribution by sexes of the ten types of crosses. As indicated in the table, the smallest number represented per cross is 17 for group 12, while the largest is 86 for group 7.

Dissection Technique.-The dissection technique was practically identical in all of the seventeen series, with the exception of the first two, when measurements and weights in addition to those reported were taken. The details of the procedure were as follows : the birds to be killed were starved from the afternoon of the day previous to the day of killing 
(birds in series 13 were fed grain early on the morning of the killing through an oversight of the attendant). On the morning of the day of dissection the birds were weighed individually and then killed by breaking the neck. The head was severed from the body and the carcasses were suspended by the legs for a period of a quarter of an hour or over to allow the drainage of blood. After this the birds were dissected in random order. The skin with the feathers was removed from the right side of the body. The right leg was removed at the acetabulum, properly marked for identification, and preserved for further treatment.

A sharp scalpel was used to remove the right tensor patagii muscles. The right pectoralis major was then dissected out with a scalpel. An incision across the insertion on the proximal end of the humerus was followed along the clavicle and down the keel of the sternum to the tip of the xiphoid process. This freed the origin of the muscle and permitted following the outside edge of it with a scalpel along the line marked by a layer of fat separating the pectoralis major from the obliquus abdominis externus. An assistant with a container of a known tare weight then obtained the gross weight of the muscle and container. In the last three series of dissections no container was used, but the various organs were weighed on a small piece of cellophane of known weight.

While the assistant was engaged in weighing the pectoralis major, the viscera of the bird were exposed and the liver dissected out. The gall bladder was cut off and the liver dried with an absorbent towel to remove the excess of blood. The liver was then weighed in the same manner as the pectoralis major, although data thus obtained are not being reported here.

The legs that were kept were roughly cleaned and then treated by a technique similar to the one used by Schneider and Dunn (1924), which involved boiling them in an alkaline solution and further cleaning. In a number of instances the bones could not be measured, usually because of overboiling the bones, but occasionally a bone was broken in the process of cleaning.

Measurement and Weighing.-Live weights of chicks up to four weeks of age were recorded to the nearest gram. Older birds were weighed to 10 grams. In the first and second series of dissections the weights of parts were recorded to $1 \mathrm{mg}$. In subsequent series the weighings were either made with an accuracy of 0.01 gram or 0.1 gram, according to the size of the parts studied. For the measurement of bones, vernier calipers calibrated to $0.01 \mathrm{~mm}$ were employed in the case of birds whose longest bone (tibiotarsus) did not exceed $75 \mathrm{~mm}$. For longer bones a simplified method was used. The bones were placed on a millimetric ruler, in iden- 
tical position for each bird and the distance between two farthest points on each bone recorded to $1 \mathrm{~mm}$.

Every dissection and every bone measurement was made by the writer in order to equalize the personal factor. This factor entered to a slight degree in the recording of weights, since five different assistants were engaged for that purpose during the investigation. However, since the sensitivity of the balances employed extended to a higher degree of precision than that used in recording the weights, the personal factor may be considered as having been held at a minimum.

The data thus obtained were then subjected to a statistical analysis.

\section{RELATIVE GROWTH}

Growth of a Part in Relation to the Whole.-The measurement of parts with respect to the whole forms a field of embryology and anatomy, which found new significance with the demonstration of the relation of the part to the whole by Huxley $(1924,1932)$. As Needham (1934) points out, both Dubois (1897) and Lapicque (1898) have approached the formulation proposed by Huxley, but it was the latter who gave an impetus to the collection of new data and to the re-examination of old. Considerable information is available on the subject in many forms of plant and animal life, and very able summaries of data gathered are given by Needham (1931) and Huxley (1932). The work on the domestic fowl, however, is rather limited, so far as the application of the simple formula of Huxley expressing the relation of the part to the whole is concerned. Most of that work has been done on embryological material, the data having been summarized by Needham (1934). The anatomical work on the posthatching growth of parts of the fowl was mentioned in an earlier section, but none of the workers concerned approached the subject either from the standpoint of possible breed differences or from the standpoint of what is termed heterogonic relation.

Obviously the growth of the organism as a whole is the sum total of the growth of its parts, while form or shape of the organism is the result of differential rate of growth of the parts, or differences in length of the growing period.

The genetics of shape has been studied particularly in plants, and the literature on the subject has been reviewed by Sinnott and Dunn (1935) and by Kaiser (1935). Most interesting results were obtained by Sinnott (1935a) and his associates (reviewed by Kaiser and by Sinnott and Dunn), indicating inheritance of shape of fruits of some plants irrespective of weight. Thus in Cucurbita pepo, Sinnott (1931) found that the particular dimensions of the fruit are a result of interaction of size and 
shape factors, which are independent of each other. Sinnott and Dunn also point out that the genetic control of shape may be vested in (1) relative rates of cell division in different regions of body or organ, (2) cell shape, (3) plane of cell division.

It is probably the particular application of the first point that is involved in this investigation. The genes being dealt with are rate genes, which are factors controlling development and determining growth gradients, similar to Goldschmidt's rate genes in the sex determination of Lymantria (1927). Pertinent instances are that of the inherited differential growth rates between polar and equatorial dimensions in the fruit of the tomato (Houghtaling, 1935) and that of single major genes controlling relative dimensional growth rates in the fruit of peppers (Kaiser, 1935).

Mathematical Expression of Heterogony.-The rate of growth of a part relative to the whole has been termed "heterogony" by Pézard (1918) and a general mathematical expression formulated for it by Huxley :

$$
y=b x^{k}
$$

where $y$ represents the part and $x$ the whole, while $b$ and $k$ are constants. Sometimes the equation is written as

$$
y=b(x-y)^{k}
$$

so as to relate the part to the remainder of the whole. This is done to avoid the absurdity of the part's eventually exceeding the whole when it grows at a faster rate. However, since growth is not infinite and the difference in $k$ between the two cases is found to be very small, equation 1 has been accepted by most workers. Needham (1934) has pointed out that the equation cannot have a true physical meaning because it would not satisfy the theory of dimensions. This follows from the fact that if $x$ is a mass, $x^{k}$ cannot be unless $k=1$, and the requirement of the theory of dimensions that the dimensions on the two sides of the relation should be equivalent is not satisfied. However, this does not invalidate the usage of the heterogonic formula for purposes of comparison.

When $k$ is higher than unity in value, the part is growing at a more rapid rate than the whole and the condition is termed positive heterogony. When $k$ is less than unity, negative heterogony is indicated. Dawes and Huxley (1934) suggest the terms "hypergony" and "hypogony" to describe the respective cases, while "isogony" has been frequently used for the cases where $k=$ one.

Robb (1929b) has drawn an analogy between the heterogonic growth relation and the conditions found when a solute is placed in two immisci- 
ble solvents in contact with each other. The distribution of the solute to the solvents will occur in a certain ratio, known as the partition coefficient. Robb suggests that the distribution of growth essentials between tissues is analagously controlled by $k$, the partition coefficient of growth.

Equation 1 represents a logarithmic straight line in which $k$ is the tangent of the angle between the straight line and the positive axis of abscissas and $\log b$ is the intercept on the axis of ordinates.

Several methods of determining the values of the parameters of this straight line are available. A crude determination may be readily made by graphic means, by using a tangent meter. A more exact solution is possible by applying the method of least squares. As Feldstein and Hersh (1935a) point out, there are two ways of doing so. The first way can be used when arithmetic values of the original data are used. If $w$ is the frequency weight, two observation equations are obtained

$$
y^{2} w(\log y-\log b-k \log x)=0
$$

and

$$
\log x\left[y^{2} w(\log y-\log b-k \log x)\right]=0
$$

From these, Feldstein and Hersh obtain the solution for $k$ in the following form:

$$
k=\frac{\Sigma y^{2} w\left(\Sigma y^{2} w \log x \log y\right)-\left(\Sigma y^{2} w \log x\right)\left(\Sigma y^{2} w \log y\right)}{\Sigma y^{2} w\left[\Sigma y^{2} w(\log x)^{2}\right]-\left(\Sigma y^{2} w \log x\right)^{2}} .
$$

The other way of arriving at the value of $k$ is to apply the least-squares method to logarithms of the original data. By a simple logarithmic transformation of equation 1 :

$$
\log y=\log b+k \log x,
$$

which represents the regression line of $\log y$ on $\log x ; k$ can be solved by the ordinary regression-coefficient equation:

$$
k=r \frac{\sigma_{\log y}}{\sigma_{\log x}}=\frac{n \Sigma \log x \log y-\Sigma \log x \Sigma \log y}{n \Sigma(\log x)^{2}-(\Sigma \log x)^{2}},
$$

where $n$ equals the total number of individuals for which the determination is made. ${ }^{4}$

Feldstein and Hersh (1935a) applied both equations 5 and 7 to Hersh's (1931) data on facet number in different bar-eyed stocks of Drosophila, and although the values obtained by the two methods were

\footnotetext{
${ }^{4}$ Since this paper went to press Osear W. Richards of Yale University has kindly called my attention to a paper by Schmalhausen (1931), which, antedating Feldstein and Hersh, gives a least-squares solution for $k$ as well as formulas for the standard errors of $k$ and of $\log b$.
} 
different, the trends were found to be similar. They were not able to establish criteria for deciding which is the preferable method. For comparative purposes it may be imagined that the method which proves to be less laborious could be chosen for the data herewith presented; and the logarithmic method, embodied in equation 7 was found to be such.

The value of the intercept of the regression line can be obtained by substitution into one of the normal equations and solution for $\log b$. Another parameter which can be used is one designated by log $a$. From equation 6 :

$$
\log b=\overline{\log } y-k \overline{\log } x .
$$

Substituting into equation 6 :

or

$$
\log y=\overline{\log } y-k \overline{\log } x+k \log x
$$

$$
\log y=\overline{\log } y+k(\log x-\overline{\log } x) ;
$$

$k$ remains here the same as in the original equation 1 , while the new parameter $\log a$ is the mean value of $\log y$ :

$$
\log a=\overline{\log } y=\frac{\Sigma \log y}{n}
$$

The standard error of $k$ is in accordance with Feldstein and Hersh $(1935 b)$ :

$$
S E_{k}=\frac{\sigma_{\log y} \sqrt{1-r^{2} \log x \log y}}{\sigma_{\log x} \sqrt{n-2}}=\sqrt{\frac{n \Sigma \log ^{2} y-(\Sigma \log y)^{2}}{n \Sigma \log x^{2}-(\Sigma \log x)^{2}}-k^{2}},
$$

making allowance for the number of degrees of freedom. The reliability of the value of $k$, or the scatter of the observation data around the straight line defined by $k$ and by $\log a$, can be determined from the usual statistical relation between a constant and its standard error. Equations 7 and 11 were used for the determination of the constants and equation 12 for the standard error of $k$. The standard errors of $\log a$ are not presented.

Hersh (1931) has presented evidence that there is a definite relation between the values of $b$ and $k$ in the bar-eyed stocks of Drosophila. $\mathrm{He}$ found that the changes in $b$ and $k$ follow the exponential function:

$$
b=B e^{-r k}
$$

where $r$ is the relative rate of decrease in $b$ per unit change in $k$, and $B$ is the value of $b$, when $k$ approaches zero. The uniform covariability of 
$b$ and $k$ may have a possible biological meaning, although Lumer (1936) questions equation 13 on mathematical grounds. Neither Huxley (1932) nor Needham (1934) attached any biological significance to the value of $b$. This may be an unnecessarily extreme point of view, since $b$ in reality is the value of $y$ when $x$ equals unity and may have a distinct bearing on the preceding developmental history. However, since no ready interpretation of $b$ is available, $\log a$ is presented in this paper as being directly available from the observation data. The value of $\log a$, of course, can be considered only as a parameter defining the regression equation, since it will be affected by the chance distribution of the various groups in different age classes at the time the observations were taken. Hence its only use for the present purposes is as a parameter, which with $k$ can be used to construct the regression equation, although it also characterizes each group. ${ }^{5}$

When the relation of skeletal growth to total body weight is considered, linear measurement is used for one coördinate and mass measurement for the other. However, weight and length of bones are related:

$$
\text { Weight }=C \text { length }{ }^{3}
$$

or written in the form of:

$$
y=C y_{1}{ }^{3}
$$

The calculation of the coefficients of heterogonic growth has been made on the basis of an equation of the type

$$
y=b x^{k}
$$

However, since only linear measurements were available on bones first

$$
y_{1}=b_{1} x^{k_{1}}
$$

was calculated, where $y_{1}$ as in 15 represents bone length. Substituting 15 in 16, and cubing :

$$
y=C b_{1}^{3} x^{3 k_{1}}
$$

Here $\log C+3 \log b_{1}$ is the intercept on the axis of ordinates when the equation is transformed into logarithmic form, while

$$
3 k_{1}=k
$$

${ }^{5}$ Since this was written my attention has been drawn to a paper by Richards (1935), wherein a critique of the concept of $k$ is presented. The objections cited include the variability of $k$ during the growing period, the inadequacy of the graphic method of estimation of $k$ values, and the oversimplification of growth processes coincident with its use. However, comparison of $k$ 's when they are considered as pure dimensionless numbers arrived at under identical conditions is permissible. 
Consequently to obtain the true coefficient of heterogonic growth of the bone lengths, the values of $k_{1}$ should be multiplied by 3 .

It has been mentioned that owing to faulty technique some of the bones were not available for measurement. Hence not all of the individuals dissected were used to determine the value of $k_{1}$, while other birds used in leg-bone computations lacked the pectoralis-major weight. Hence, a

TABLE 2

Number of Individuals Used for the Determination of Relative Growth Constants by Groups

\begin{tabular}{|c|c|c|c|c|c|c|c|c|}
\hline \multirow{3}{*}{ Mating } & \multicolumn{4}{|c|}{ Males } & \multicolumn{4}{|c|}{ Females } \\
\hline & \multirow[b]{2}{*}{ Group } & \multicolumn{3}{|c|}{ Relation studied } & \multirow[b]{2}{*}{ Group } & \multicolumn{3}{|c|}{ Relation studied } \\
\hline & & $\begin{array}{c}\text { Pectoralis } \\
\text { major } \\
\text { and } \\
\text { body } \\
\text { weight }\end{array}$ & $\begin{array}{c}\text { Leg bones } \\
\text { and } \\
\text { leg length } \\
\text { or body } \\
\text { weight }\end{array}$ & $\begin{array}{c}\text { Pectoralis } \\
\text { major } \\
\text { weight } \\
\text { and leg } \\
\text { length }\end{array}$ & & $\begin{array}{c}\text { Pectoralis } \\
\text { major } \\
\text { and } \\
\text { body } \\
\text { weight }\end{array}$ & $\begin{array}{l}\text { Leg bones } \\
\text { and } \\
\text { leg length } \\
\text { or body } \\
\text { weight }\end{array}$ & $\begin{array}{l}\text { Pectoralis } \\
\text { major } \\
\text { weight } \\
\text { and leg } \\
\text { length }\end{array}$ \\
\hline $\begin{array}{l}\text { Barred Plymouth } \\
\text { Rock }\end{array}$ & 1 & 45 & 43 & 42 & 2 & 42 & 30 & 30 \\
\hline Black Minorca......... & 3 & 35 & 29 & 29 & 4 & 41 & 37 & $\begin{array}{l}58 \\
37\end{array}$ \\
\hline $1 \times 4 \ldots \ldots \ldots \ldots \ldots$ & 5 & 38 & 35 & 35 & 6 & 33 & 28 & 28 \\
\hline $3 \times 2 \ldots \ldots \ldots \ldots \ldots$ & 7 & 86 & 82 & 82 & 8 & 57 & 51 & 51 \\
\hline $1 \times 6 \ldots \ldots \ldots \ldots \ldots$ & 9 & 35 & 36 & 35 & 10 & 35 & 34 & 33 \\
\hline $1 \times 8 \ldots \ldots \ldots \ldots \ldots$ & 11 & 20 & 20 & 20 & 12 & 17 & 17 & 17 \\
\hline $3 \times 6 \ldots \ldots \ldots \ldots \ldots$ & 13 & 36 & 35 & 35 & 14 & 40 & 40 & 40 \\
\hline $3 \times 8 \ldots \ldots \ldots \ldots \ldots$ & 15 & 26 & 26 & 26 & 16 & 28 & 28 & 28 \\
\hline $5 \times 2 \ldots \ldots \ldots \ldots \ldots$ & 17 & 35 & 35 & 35 & 18 & 36 & 34 & 34 \\
\hline $7 \times 2 \ldots \ldots \ldots \ldots \ldots$ & 19 & 39 & 39 & 39 & 20 & 29 & 31 & 29 \\
\hline
\end{tabular}

discrepancy arose in numbers for the various determinations. Table 2 presents the actual number of birds involved for each group for each calculation.

\section{PECTORALIS MAJOR}

Figure 1 presents the logarithmic plot of the weight of the pectoralis major against body weight for the male progeny of the different matings. It is used to illustrate plots made for all of the structures studied for the two sexes, where individual observations were used. A straight-line relation is shown in this figure, indicating that $k$ is fairly constant for the post-hatching period of growth. Moreover, it can be seen that in all of the ten types of matings a uniformity exists in the logarithmic ratio of the pectoralis major to the body weight. The figure in itself, however, does not give a clear indication as to whether or not there are any definite differences in the value of $k$ between crosses. Any minute but significant differences would not show up in graphic form. 
Table 3 gives the actual values of $k$, together with their standard errors, for both the males and the females. It should be noted that in the calculation of the standard errors in some cases cumulative differences in decimal places brought the value under the square root in equation 12 to zero or even to a negative number. In these cases, the standard error

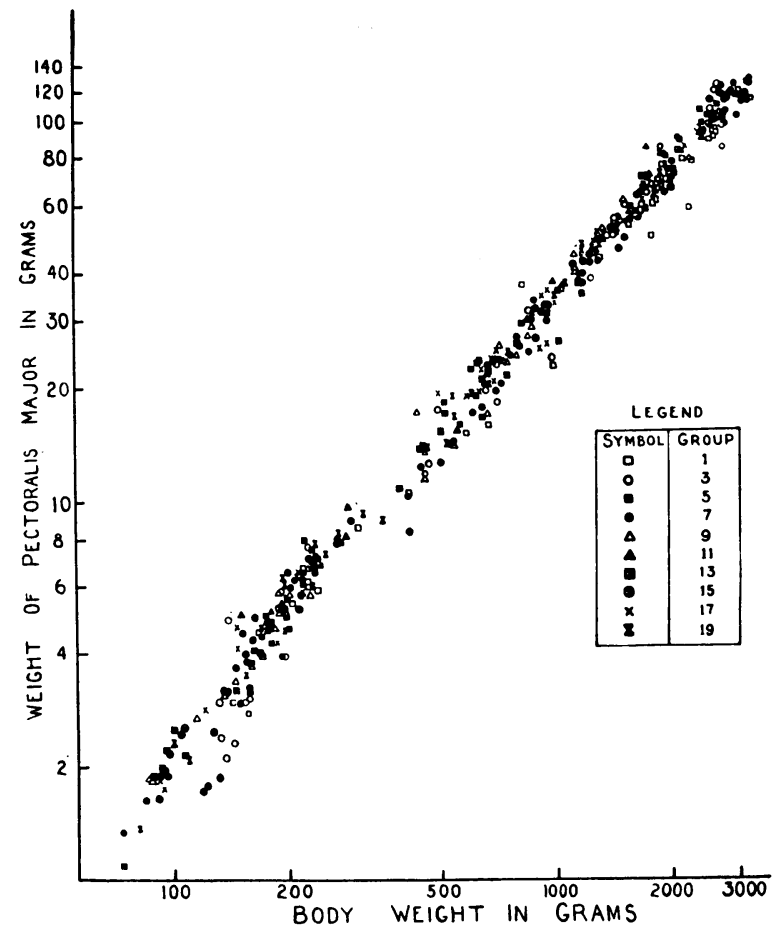

Fig. 1.-Weight of the pectoralis major of the males plotted against body weight on a double log grid. For key to group numbers see table 1.

was estimated on the basis of a minimum difference between the two expressions under the square root in equation 12 . It may be readily observed that while the range of the values varies from 1.148 for the purebred Plymouth Rock males and females to 1.249 for the purebred Minorca males, the standard errors are of such a magnitude as to render no difference statistically significant. In these extreme cases the actual standard errors are available and not the estimated values as stated above.

So far as the differences between the sexes are concerned, in most cases the females showed a higher $k$ value than the males of the corresponding mating, though at least one case of the reversed condition can be ob- 
served. If it can be said that all of the $k$ values for the same sex are essentially the same and the apparent differences are due to chance variation, no significance can be attached to the difference between the sexes since the actual values overlap considerably throughout the series of 20 groups. However, when the males and females in the various groups are paired and analyzed by Student's method, a definite tendency may be noted favoring a higher $k$ value for the females. The value of $z$ is 0.731 , which is approximately equivalent to $34: 1$ odds on significance. This would in-

TABLE 3

Relative Growth Constants for the Weight of the Pectoralis Major with RESPECT TO BODY WEIGHT

\begin{tabular}{|c|c|c|c|c|c|c|}
\hline \multirow{2}{*}{ Mating } & \multicolumn{3}{|c|}{ Males } & \multicolumn{3}{|c|}{ Females } \\
\hline & Group & $k$ & $\log a$ & Group & $k$ & $\log a$ \\
\hline Barred Plymouth Rock & 1 & $1.148 \pm 0.130$ & 1.596 & 2 & $1.148 \pm 0.125$ & 1.419 \\
\hline Black Minorca......... & 3 & $1.249 \pm 0.141$ & 1.351 & 4 & $1.231 \pm 0.040$ & 1.419 \\
\hline $1 \times 4 \ldots \ldots \ldots \ldots \ldots \ldots$ & 5 & $1.167 \pm 0.032$ & 1.348 & 6 & $1.183 \pm 0.114$ & 1. 269 \\
\hline $3 \times 2 \ldots \ldots \ldots \ldots \ldots \ldots$ & 7 & $1.199 \pm 0.110$ & 1.336 & 8 & $1.201 \pm 0.179$ & 1.280 \\
\hline $1 \times 6 \ldots \ldots \ldots \ldots \ldots \ldots$ & 9 & $1.187 \pm 0.084$ & 1.178 & 10 & $1.244 \pm 0.110$ & 1.150 \\
\hline $1 \times 8 \ldots$ & 11 & $1.172 \pm 0.232$ & 1.438 & 12 & $1.248 \pm 0.055$ & 1.201 \\
\hline $3 \times 6 \ldots$ & 13 & $1.201 \pm 0.095$ & 1.074 & .14 & $1.210 \pm 0.176$ & 1.173 \\
\hline $3 \times 8 \ldots \ldots \ldots \ldots \ldots \ldots$ & 15 & $1.179 \pm 0.126$ & 1.112 & 16 & $1.246 \pm 0.138$ & 1.097 \\
\hline $5 \times 2 \ldots \ldots \ldots \ldots \ldots \ldots$ & 17 & $1.176 \pm 0.110$ & 1.311 & 18 & $1.196 \pm 0.137$ & 1.262 \\
\hline $7 \times 2 \ldots \ldots$ & 19 & $1.201 \pm 0.095$ & 1.261 & 20 & $1.204 \pm 0.184$ & 1.236 \\
\hline
\end{tabular}

dicate that if the $k$ values were ealculated for the entire population and separately for the two sexes, the $k$ for the females would be higher than that for the males.

Though no data exactly comparable can be found in the literature, it may be of interest to note that Mitchell, Card, and Hamilton (1926), working with White Plymouth Rocks, found that the percentage of flesh and fat in the carcass is higher in females than in males of the same weight. A similar condition was found by the same workers (1931) to prevail in White Leghorns. When the relative increase in the weight of flesh and fat in the carcass was calculated with respect to increase in body weight, they found that it was greater in cockerels than in pullets. The discrepancy here is probably due to the fact that at the time of hatch the standard of comparison of body weight was higher for the pullets than for the cockerels, while the reverse was true in later stages.

Irrespective of sex, the weight of the pectoralis major increased more rapidly than the weight of the whole of the body, and thus presented a case of hypergony. Log $a$ is also shown in table 3, and from this parameter and the value of $k$, the regression equation can be constructed for 
each one of the twenty groups studied: With a similar range of weights for the parental crosses, it is highly significant that the equations do not materially differ from each other. In general, the Plymouth Rock is considered to be a better meat-type bird than the Minorca. Here, however, it may be seen that the amount of fleshing, so far as it can be judged from the weight of the pectoralis major, is the same in the two breeds. A comparison of the data in the two reports of Mitchell, Card, and Hamilton $(1926,1931)$ reveals that the Leghorn, a breed definitely not possessing

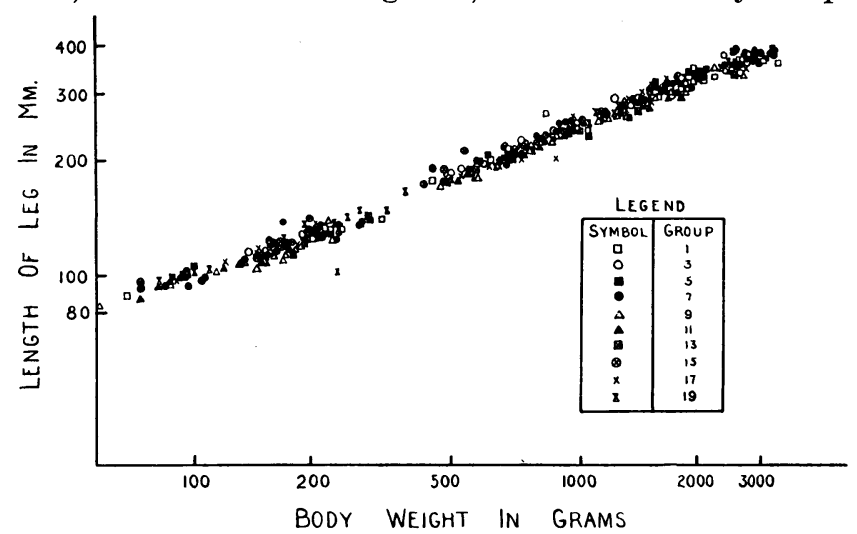

Fig. 2.- - Leg length of the males plotted against body weight on a double log grid. For key to group numbers see table 1 .

high meat quality, has at the same weights as the Plymouth Rock, a higher percentage of flesh. In this instance, however, the latter reaches a distinctly higher adult weight (Brody, 1926) and possesses a more rapid rate of growth (Asmundson and Lerner, 1934), which does not seem to be the case with the two breeds under comparison here. Thus from the practical point of view it may seem that the value of Minorcas as meat producers has been underestimated unless there is a difference in the growth of the two breeds with respect to time. Investigation of this point is impossible with the material available because of the relatively small numbers of individuals in each hatch.

\section{LEG BONES}

A logarithmic plot of the total leg length obtained by addition of separate arithmetic values for the femur, tibiotarsus, and tarsometatarsus against body weight is given in figure 2 for the males. The females show a comparable distribution, the plot not being included here, as in the case of the pectoralis major, for reasons of economy of space. It may be noted, however, that a slight flattening of the line at the extreme weight range 
is observed in the females due to continued deposition of fat after linear growth has ceased. In general, the observations made about the pectoralis major may be repeated here. A straight-line relation is indicated and a uniform tendency in all of the ten groups can be noted.

Table 4 gives the values of $k_{1}$, for the whole leg as well as for the constituent bones in relation to body weights, while table 5 shows the values

TABLE 4

Values of $k_{1}$ for the Total Leg Length and Length of Constituent Bones in Relation to Body Weight

\begin{tabular}{|c|c|c|c|c|c|}
\hline Mating & Group & Total leg* & Femur* & Tibiotarsus* & Tarsometatarsus \\
\hline \multirow{2}{*}{ Barred Plymouth Rock.... } & 1 & $0.394 \pm 0.076$ & $0.365 \pm 0.077$ & $0.405 \pm 0.063$ & $0.411 \pm 0.077$ \\
\hline & 2 & $0.354 \pm 0.069$ & $0.335 \pm 0.053$ & $0.364 \pm 0.066$ & $0.363 \pm 0.093$ \\
\hline \multirow{2}{*}{ Black Minorca............. } & 3 & $0.399 \pm 0.028$ & $0.361 \pm 0.044$ & $0.420 \pm 0.142$ & $0.410 \pm 0.118$ \\
\hline & 4 & $0.361 \pm 0.026$ & $0.334 \pm 0.024$ & $0.373 \pm 0.004$ & $0.374 \pm 0.054$ \\
\hline \multirow{2}{*}{$1 \times 4 \ldots \ldots \ldots \ldots \ldots \ldots \ldots$} & 5 & $0.398 \pm 0.047$ & $0.370 \pm 0.041$ & $0.409 \pm 0.050$ & $0.411 \pm 0.048$ \\
\hline & 6 & $0.384 \pm 0.053$ & $0.363 \pm 0.049$ & $0.393 \pm 0.050$ & $0.391 \pm 0.069$ \\
\hline \multirow{2}{*}{$3 \times 2 \ldots \ldots \ldots \ldots \ldots \ldots \ldots$} & 7 & $0.399 \pm 0.032$ & $0.373 \pm 0.032$ & $0.408 \pm 0.032$ & $0.419 \pm 0.032$ \\
\hline & 8 & $0.394 \pm 0.055$ & $0.374 \pm 0.032$ & $0.400 \pm 0.045$ & $0.410 \pm 0.063$ \\
\hline \multirow{2}{*}{$1 \times 6}$. & 9 & $0.400 \pm 0.010$ & $0.382 \pm 0.010$ & $0.401 \pm 0.010$ & $0.414 \pm 0.045$ \\
\hline & 10 & $0.396 \pm 0.032$ & $0.384 \pm 0.045$ & $0.396 \pm 0.010$ & $0.411 \pm 0.045$ \\
\hline \multirow{2}{*}{$1 \times 8 \ldots \ldots \ldots \ldots \ldots \ldots \ldots$} & 11 & $0.410 \pm 0.077$ & $0.372 \pm 0.077$ & $0.418 \pm 0.084$ & $0.433 \pm 0.095$ \\
\hline & 12 & $0.389 \pm 0.032$ & $0.365 \pm 0.032$ & $0.397 \pm 0.010$ & $0.405 \pm 0.032$ \\
\hline \multirow{2}{*}{$3 \times 6$} & 13 & $0.399 \pm 0.054$ & $0.367 \pm 0.045$ & $0.402 \pm 0.055$ & $0.427 \pm 0.063$ \\
\hline & 14 & $0.411 \pm 0.055$ & $0.375 \pm 0.285$ & $0.417 \pm 0.055$ & $0.436 \pm 0.077$ \\
\hline \multirow{2}{*}{$3 \times 8 \ldots \ldots \ldots \ldots \ldots \ldots \ldots$} & 15 & $0.411 \pm 0.045$ & $0.384 \pm 0.182$ & $0.414 \pm 0.063$ & $0.433 \pm 0.105$ \\
\hline & 16 & $0.412 \pm 0.045$ & $0.380 \pm 0.055$ & $0.415 \pm 0.155$ & $0.441 \pm 0.063$ \\
\hline \multirow{2}{*}{$5 \times 2 \ldots \ldots \ldots \ldots \ldots \ldots \ldots$} & 17 & $0.397 \pm 0.045$ & $0.371 \pm 0.045$ & $0.404 \pm 0.045$ & $0.417 \pm 0.063$ \\
\hline & 18 & $0.417 \pm 0.045$ & $0.381 \pm 0.045$ & $0.430 \pm 0.032$ & $0.439 \pm 0.032$ \\
\hline \multirow{2}{*}{$7 \times 2 \ldots \ldots \ldots \ldots \ldots \ldots \ldots$} & 19 & $0.410 \pm 0.063$ & $0.380 \pm 0.055$ & $0.413 \pm 0.063$ & $0.433 \pm 0.071$ \\
\hline & 20 & $0.403 \pm 0.071$ & $0.382 \pm 0.045$ & $0.412 \pm 0.055$ & $0.417 \pm 0.063$ \\
\hline
\end{tabular}

* Standard errors below 0.032 are estimates.

of the other parameter of the regression equation. As already mentioned, the true coefficient of heterogonic growth can be obtained by multiplying $k_{1}$ by 3 .

The uniformity of the $k_{1}$ values for the total length of the leg is very striking. Not only do the two parental breeds show the same logarithmic relation between leg length and total body weight, but apparently, as seen from the graphic representation, the actual leg length values are the same in the two breeds when individuals of similar weights are compared. The seeming difference in appearance of the legs of the two breeds 
is evidently not due to differences in the auxano-differentiation of the bones nor to differential length. A possibility exists that it is either a postural difference or merely a superficial difference based on a different type of feathering in the region of the pelvic girdle. It is, of course, highly probable that other breeds of poultry show real differences in the

TABLE 5

Values of Log $a$ For Total Leg Length and Length of Constituent Bones

\begin{tabular}{|c|c|c|c|c|c|}
\hline Mating & Group & Total leg & Femur & Tibiotarsus & Tarsometatarsus \\
\hline Barred Plymouth Rock.... & $\left\{\begin{array}{l}1 \\
2\end{array}\right.$ & $\begin{array}{l}2.429 \\
2.350\end{array}$ & $\begin{array}{l}1.894 \\
1.825\end{array}$ & $\begin{array}{l}2.047 \\
1.969\end{array}$ & $\begin{array}{l}1.894 \\
1.805\end{array}$ \\
\hline Black Minorca ........... & $\left\{\begin{array}{l}3 \\
4\end{array}\right.$ & $\begin{array}{l}2.392 \\
2.377\end{array}$ & $\begin{array}{l}1.858 \\
1.849\end{array}$ & $\begin{array}{l}2.007 \\
1.994\end{array}$ & $\begin{array}{l}1.862 \\
1.839\end{array}$ \\
\hline $1 \times 4 \ldots$ & $\left\{\begin{array}{l}5 \\
6\end{array}\right.$ & $\begin{array}{l}2.341 \\
2.295\end{array}$ & $\begin{array}{l}1.812 \\
1.775\end{array}$ & $\begin{array}{l}1.957 \\
1.908\end{array}$ & $\begin{array}{l}1.801 \\
1.752\end{array}$ \\
\hline $3 \times 2$. & $\left\{\begin{array}{l}7 \\
8\end{array}\right.$ & $\begin{array}{l}2.345 \\
2.316\end{array}$ & $\begin{array}{l}1.817 \\
1.794\end{array}$ & $\begin{array}{l}1.958 \\
1.934\end{array}$ & $\begin{array}{l}1.808 \\
1.775\end{array}$ \\
\hline $1 \times 6 \ldots$ & $\left\{\begin{array}{r}9 \\
10\end{array}\right.$ & $\begin{array}{l}2.250 \\
2.234\end{array}$ & $\begin{array}{l}1.730 \\
1.718\end{array}$ & $\begin{array}{l}1.862 \\
1.848\end{array}$ & $\begin{array}{l}1.711 \\
1.688\end{array}$ \\
\hline $1 \times 8 \ldots$ & $\left\{\begin{array}{l}11 \\
12\end{array}\right.$ & $\begin{array}{l}2.339 \\
2.249\end{array}$ & $\begin{array}{l}1.816 \\
1.729\end{array}$ & $\begin{array}{l}1.952 \\
1.866\end{array}$ & $\begin{array}{l}1.802 \\
1.704\end{array}$ \\
\hline $3 \times 6$. & $\left\{\begin{array}{l}13 \\
14\end{array}\right.$ & $\begin{array}{l}2.243 \\
2.264\end{array}$ & $\begin{array}{l}1.725 \\
1.744\end{array}$ & $\begin{array}{l}1.854 \\
1.879\end{array}$ & $\begin{array}{l}1.703 \\
1.728\end{array}$ \\
\hline $3 \times 8$. & $\left\{\begin{array}{l}15 \\
16\end{array}\right.$ & $\begin{array}{l}2.256 \\
2.238\end{array}$ & $\begin{array}{l}1.732 \\
1.719\end{array}$ & $\begin{array}{l}1.868 \\
1.852\end{array}$ & $\begin{array}{l}1.702 \\
1.694\end{array}$ \\
\hline $5 \times 2 \ldots$ & $\left\{\begin{array}{l}17 \\
18\end{array}\right.$ & $\begin{array}{l}2.314 \\
2.295\end{array}$ & $\begin{array}{l}1.789 \\
1.774\end{array}$ & $\begin{array}{l}1.926 \\
1.911\end{array}$ & $\begin{array}{l}1.777 \\
1.751\end{array}$ \\
\hline $7 \times 2$. & $\left\{\begin{array}{l}19 \\
20\end{array}\right.$ & $\begin{array}{l}2.294 \\
2.253\end{array}$ & $\begin{array}{l}1.773 \\
1.731\end{array}$ & $\begin{array}{l}1.906 \\
1.867\end{array}$ & $\begin{array}{l}1.758 \\
1.711\end{array}$ \\
\hline
\end{tabular}

length of leg, but differences in the heterogonic relation between the leg and the body still remain to be determined in these cases.

Such a case is available in cattle, where Swett, Graves, and Miller (1928) compared the measurements of a Jersey cow with those of an Aberdeen Angus cow. The former exihibited longer leg bones than the latter but weighed less. Though the constant differential growth ratio cannot be determined from the data supplied by these workers, it is possible that in the Jersey the leg bones show a more positive heterogony than do those of the Aberdeen Angus. This, of course, is not definite evidence of a hereditary condition since the intercept of relation or the nutritional state of the animals may be the responsible factor. 
Kopee (1927) found that the Orpingtons have longer tibiotarsi and tarsometatarsi than Leghorns. The length of the bones of the hybrids was found to be in most cases closer to the longer-boned parent. However, the differences are small, the number of birds was small, and overlapping of ranges is indicated; furthermore, no tests of statistical significance are given.

Ghigi and Taibell (1927) have also reported that in an Indian Game $\times$ Leghorn cross, the $F_{1}$ tarsi were of the same length as that of the longer-boned parents. No actual figures were cited by them.

Lerner and Asmundson (1932) presented measurements of the tarsometatarsi of Ancona $\times$ Light Sussex hybrids and backerosses to parental breeds at twelve weeks of age. They found that there was a significant difference in the length of the bone studied between the two types of backcross progeny in favor of the Light Sussex $\times \mathrm{F}_{1}$ mating. However, these birds were also the heaviest and thus possibly the heterogonic relation of the two was the same. This is further supported by the fact that when the logarithmic ratios of the mean bone length to mean body weight as given in their paper are calculated, they are found to be practically identical for both types of backerosses. The same is true for the data of Kopeć (1927) with respect to his parental breeds.

Thus the question as to whether or not conditions similar to those found by Swett, Graves, and Miller (1928) in eattle exist in the normal-sized breeds of domestic fowl remains open. The term "normal-sized" refers here and hereafter to breeds other than Bantams. The relation in Bantams was determined and will be discussed at length in a separate section.

It may be noted than when the tabular values of $k_{1}$ are multiplied by 3 to obtain $k$, hypergony is indicated for the whole leg and for its constituent bones. This holds true for all of the birds studied here irrespective of origin and confirms Latimer's findings (1927) that the rate of growth of the leg bones in the fowl is higher than the rate of body weight growth. A sex difference in the $k_{1}$ value for leg length can also be observed here. Student's method of pairing shows that the odds for significance of this difference with a $z$ value of 1.444 are over 1000 to 1 . The sex difference here is in favor of the males, once more in accordance with the results of Latimer (1927), who shows that the male bones increase from hatching weight to maturity to a greater extent than do female bones, with the exception of the femur, where no difference was found.

The interrelation of the three bones may be best illustrated by the use of the coefficient of heterogonic growth with respect to total leg length rather than to body weight. 


\section{GROWTH GRADIENTS IN THE LEG}

The values of the exponent $k$ for the femur, tibiotarsus, and tarsometatarsus, when the leg length is considered as the whole, are shown in table 6 . The values of $\log a$ (mean logarithms of leg length) for these regression equations remain the same as for the body weight and are shown in table 5 . The three values of $k$ show a significant trend within each of the

TABLE 6

Values of $k$ For Length of Leg Bones with Respect to Total Length of Leg

\begin{tabular}{|c|c|c|c|c|}
\hline Mating & Group & Femur* & Tibiotarsus* & Tarsometatarsus* \\
\hline Barred Plymouth Rock..... & $\left\{\begin{array}{l}1 \\
2\end{array}\right.$ & $\begin{array}{l}0.925 \pm 0.095 \\
0.940 \pm 0.053\end{array}$ & $\begin{array}{l}1.025 \pm 0.010 \\
1.028 \pm 0.010\end{array}$ & $\begin{array}{l}1.041 \pm 0.077 \\
1.027 \pm 0.167\end{array}$ \\
\hline Black Minorca.... & $\left\{\begin{array}{l}3 \\
4\end{array}\right.$ & $\begin{array}{l}0.915 \pm 0.010 \\
0.918 \pm 0.116\end{array}$ & $\begin{array}{l}1.058 \pm 0.335 \\
1.026 \pm 0.097\end{array}$ & $\begin{array}{l}1.031 \pm 0.010 \\
1.032 \pm 0.157\end{array}$ \\
\hline $1 \times 4 \ldots$ & $\left\{\begin{array}{l}5 \\
6\end{array}\right.$ & $\begin{array}{l}0.925 \pm 0.045 \\
0.945 \pm 0.010\end{array}$ & $\begin{array}{l}1.024 \pm 0.045 \\
1.021 \pm 0.045\end{array}$ & $\begin{array}{l}1.028 \pm 0.045 \\
1.020 \pm 0.094\end{array}$ \\
\hline $3 \times 2$. & $\left\{\begin{array}{l}7 \\
8\end{array}\right.$ & $\begin{array}{l}0.938 \pm 0.010 \\
0.944 \pm 0.063\end{array}$ & $\begin{array}{l}1.021 \pm 0.045 \\
1.010 \pm 0.071\end{array}$ & $\begin{array}{l}1.050 \pm 0.032 \\
1.046 \pm 0.010\end{array}$ \\
\hline $1 \times 6 \ldots$ & $\left\{\begin{array}{r}9 \\
10\end{array}\right.$ & $\begin{array}{l}0.952 \pm 0.063 \\
0.976 \pm 0.010\end{array}$ & $\begin{array}{l}1.006 \pm 0.010 \\
0.999 \pm 0.010\end{array}$ & $\begin{array}{l}1.037 \pm 0.084 \\
1.045 \pm 0.010\end{array}$ \\
\hline $1 \times 8$. & $\left\{\begin{array}{l}11 \\
12\end{array}\right.$ & $\begin{array}{l}0.907 \pm 0.045 \\
0.937 \pm 0.071\end{array}$ & $\begin{array}{l}1.021 \pm 0.063 \\
1.020 \pm 0.010\end{array}$ & $\begin{array}{l}1.063 \pm 0.010 \\
1.040 \pm 0.010\end{array}$ \\
\hline $3 \times 6$. & $\left\{\begin{array}{l}13 \\
14\end{array}\right.$ & $\begin{array}{l}0.925 \pm 0.010 \\
0.913 \pm 0.675\end{array}$ & $\begin{array}{l}1.011 \pm 0.063 \\
1.014 \pm 0.010\end{array}$ & $\begin{array}{l}1.076 \pm 0.010 \\
1.061 \pm 0.114\end{array}$ \\
\hline $3 \times 8$. & $\left\{\begin{array}{l}15 \\
16\end{array}\right.$ & $\begin{array}{l}0.927 \pm 0.443 \\
0.926 \pm 0.010\end{array}$ & $\begin{array}{l}1.012 \pm 0.010 \\
1.006 \pm 0.362\end{array}$ & $\begin{array}{l}1.058 \pm 0.202 \\
1.076 \pm 0.010\end{array}$ \\
\hline $5 \times 2$. & $\left\{\begin{array}{l}17 \\
18\end{array}\right.$ & $\begin{array}{l}0.937 \pm 0.010 \\
0.912 \pm 0.063\end{array}$ & $\begin{array}{l}1.016 \pm 0.010 \\
1.029 \pm 0.010\end{array}$ & $\begin{array}{l}1.057 \pm 0.010 \\
1.047 \pm 0.105\end{array}$ \\
\hline $7 \times 2$ & $\left\{\begin{array}{l}19 \\
20\end{array}\right.$ & $\begin{array}{l}0.927 \pm 0.010 \\
0.938 \pm 0.089\end{array}$ & $\begin{array}{l}1.011 \pm 0.010 \\
1.013 \pm 0.110\end{array}$ & $\begin{array}{l}1.056 \pm 0.071 \\
1.028 \pm 0.095\end{array}$ \\
\hline
\end{tabular}

* Standard errors below 0.032 are estimates.

groups, though no difference in $k$ for the same bones in different groups can be noted. The highest $k$ in seventeen of the twenty groups is for the tarsometatarsus while the femur exhibits the lowest value in every case without exception. That the $k$ for tarsometatarsus is significantly higher than that for the tibiotarsus is shown by Student's method of pairing. The value of $z$ obtained is 1.125 , which for twenty pairs is equivalent to odds of over 10,000 to 1 ; this presents a highly significant difference. Thus the most actively growing bone is the distal one and the slowest-growing one is the proximal. 
This finding can be interpreted to mean that growth gradients exist in the posterior limb of the fowl, with the center of growth-retarding influences lying at the proximal end, or conversely with the center of growth activity lying at the distal end. The effect is radiated toward the other end, so that the tarsometatarsus in the first case or the femur in the second falls under those influences to a lesser degree than the other bones. A suggestion that this may be the case was developed by Huxley (1932) on the basis of the data on rate of growth of the leg bones of chicken embryos of Schmalhausen and Stepanowa (1926). He also cites Hutt (1929) who found that castration in the White Leghorn changes the length of the leg bones to a variable degree, increasing the femur by 3.0 per cent, the tibiotarsus by 3.4 per cent, and the tarsometatarsus by 3.9 per cent. The trend of this gradation is comparable to the one found in the data herewith presented. It also parallels the trend found by Landauer (1934) and confirmed by Lerner (1936) in the reduction of bone length in Creeper fowls. Furthermore, Rulon (1935) found reduction of Janus green in the limb bud of chicken embryos to show a distal-proximal gradation.

On the other hand, Nevalonnyi and Podhradsky (1930), working with two experimental birds, found that the positive effect of excess of thyroid on the leg bones was centrifugal, rather than centripetal. The growth of the femur was encouraged, the tibiotarsus was intermediate and the tarsometatarsus decreased in length. This is not necessarily a contradiction to the present findings or those of Hutt (1929) even when the small numbers involved are overlooked. The effect of thyroid extracts on genetic growth-retarding factors probably needs more elaborate investigation before such a conclusion can be made.

It may be mentioned here that Green (1933b) found evidence of gradients in the crania of mice, using methods of analysis similar to those here presented. Of considerable interest also is his finding that first-generation hybrids exhibit in many of the cases higher values of $k$ than the parents. Green considers this a manifestation of heterosis. One (zygomatic width) out of the seven dimensions studied presented an intermediate condition between the $k$ value of the two parents. This may be compared with Coffman's hypothesis of heterosis (1933), which presents the view that the phenomenon of hybrid vigor is specific for parts. No evidence for the existence of heterosis for any of the structures studied can be seen in the data presented in this paper. This may not hold true if the analysis were based on a time rather than on a body-weight scale. The material on hand was, however, as previously mentioned, not found suitable for such an analysis, because of the small number of birds of each sex and each group per hatch. 
Table 6 also shows that the tibiotarsus and the tarsometatarsus exhibit hypergony, while the femur shows hypogony. The net value of $k$ for the leg length is, then, a result of positive tendencies in the case of the distal bones and a negative tendency in the case of the proximal one.

Correlations.-Correlations between the $k$ values of the three bones with respect to body weight and the $k$ for the total leg length were computed and are of a very high magnitude, owing to a certain amount of spuriousness. Thus the coefficient for the femur-leg relation is $0.902 \pm$ 0.042 ; for the tibiotarsus-leg, $0.957 \pm 0.019$; and for the tarsometatarsus-leg, $0.983 \pm 0.008$. Evidently not the relative length of a bone, but rather its respective rate of growth, determines its contribution to the rate of the whole, as shown by the gradation of the coefficient values.

The correlation coefficients determined between the $k$ values of the three bones are also of some interest. The femur - tarsometatarsus shows the relation of least magnitude, with the coefficient of $0.788 \pm 0.085$. The femur-tibiotarsus relation is next, the coefficient of correlation here equaling $0.795 \pm 0.082$, while the tibiotarsus-tarsometatarsus relation exhibits a coefficient of $0.966 \pm 0.015$. The difference is further accentuated when partial correlations are considered: the three coefficients in the same order are $0.127 \pm 0.220,0.213 \pm 0.214$, and $0.909 \pm 0.039$. Multiple coefficients of correlation were also calculated, treating each bone in turn as the dependent variable and the other two as independent variables. A four-variable system of correlation, with the total leg length as the dependent and the three individual bones as the independent, was also set up. In all of the cases but one, the multiple coefficients fell into the range between 0.960 and 1.000 . The single exception was the correlation coefficient of the femur with the other two bones, its value being $0.801 \pm$ 0.080 .

Thus it may be seen that the constant $k$ of the femur is to a certain degree independent of the $k$ values of the tibiotarsus and the tarsometatarsus. Wright (1932) concluded that only 8 per cent of the total variance in the femur length of White Leghorn hens may be assigned to special femoral factors, a figure closely approaching in value the 7 per cent of the variance of the tibia due to special tibial factors. If this conclusion is accepted, the correlation coefficients presented here must be interpreted to indicate a differential response of the femur to factors common to the whole leg.

There are also other points to be considered in this connection. Landauer (1934) points out that in the Creeper stock the susceptibility to growth retardation is proportionate to the time the bone is laid down during development. At the same time he finds that the greatest reduc- 
tion occurs in the bone with the greatest inherent growth capacity, or having ultimately the greatest length. Under normal conditions, as here found, the bone to be laid down latest (tarsometatarsus) grows the fastest, eventually exceeding in length the ontogenetically oldest bone (femur). The longest bone (tibiotarsus) is laid down after the femur but grows at a more rapid rate, so that it greatly exceeds the femur in length even by the time of hatching. Its rate, however, is sufficiently close to that of the tarsometatarsus to maintain its relatively greater length throughout the posthatching period of growth. Thus through invoking positional effect and differential time of origin, no special factors for rate of growth need be postulated for the three leg bones. Common factors eliciting a differential response may well explain the situation.

Sex Differences.-With regard to the sex differences, the results of Student's method of analysis for the three bones are as follows : the tibiotarsus and the tarsometatarsus show higher $k$ values for the males, the odds on significance being approximately $81 / 2$ to 1 and 19 to 1 , respectively; the femur exhibits a higher $k$ for females, with 6 to 1 odds on the significance of the difference. Since the odds are so low, none of the bones present individually a real sex difference in heterogony. Such a difference for the total leg length can be adjudged to be due to small differences in the three bones, not significant by themselves. The trend of significance is in line with the growth gradients observed.

In general, the values of table 4 and table 6 are different expressions of the same situations. The ratio of $k_{1}$ to $k$ for each bone should be equal to the $k_{1}$ value of the leg length with respect to body weight. This holds true for all of the cases, any deviations being due to accumulated fourthplace decimal differences.

\section{RELATION OF THE LEG LENGTH TO THE PECTORALIS MAJOR}

Table 7 gives the values of the exponent in the relation

$$
y=b x^{k}
$$

where $y$ stands for pectoralis weight and $x$ for leg length. The same table also gives the values of the parameter $\log a$ (mean values of $\log y$ ) in accordance with equation 11 . It should be noted that here again a linear measurement is equated to a mass measurement. However, contrary to what was the case when the growth of leg bones was compared to the growth in body weight, it is the linear measurement which is treated here as a whole, rather than the mass. This was dictated by practical consid- 
erations, since the value of the denominator in equation 7 was already available for cases where leg length was considered as the whole.

In accordance with the equation

$$
\text { Weight }=C \text { length }{ }^{3},
$$

isogony would be indicated by a $k$ value of 3 . It may be seen that the values obtained are very close to 3 and in no case show a significant deviation from it.

Applying Student's method of analysis to deviations from the value of $3, a z$ value of 0.322 is obtained, with the low odds of 10 to 1 on significance. It may then be concluded that the leg grows at the same rate as the pectoralis, which is a confirmation of the values of $k$ of the two structures with respect to body weight. However, the males show slight hypogony

TABLE 7

Relative Growth Constants for the Weight of the Pectoralis Major with Respect to Leg Length

\begin{tabular}{|c|c|c|c|c|c|c|}
\hline \multirow{2}{*}{ Mating } & \multicolumn{3}{|c|}{ Males } & \multicolumn{3}{|c|}{ Females } \\
\hline & Group & $k$ & $\log a$ & Group & $k$ & $\log a$ \\
\hline Barred Plymouth Rock & 1 & $2.674 \pm 0.377$ & 1.669 & 2 & $3.191 \pm 0.385$ & 1.482 \\
\hline Black Minorca......... & 3 & $2.987 \pm 0.347$ & 1.513 & 4 & $3.260 \pm 0.522$ & 1.526 \\
\hline $1 \times 4 \ldots \ldots \ldots \ldots \ldots \ldots$ & 5 & $2.851 \pm 0.344$ & 1.408 & 6 & $3.015 \pm 0.489$ & 1.340 \\
\hline $3 \times 2 \ldots$ & 7 & $2.945 \pm 0.326$ & 1.382 & 8 & $2.824 \pm 0.672$ & 1.380 \\
\hline $1 \times 6 \ldots$ & 9 & $2.915 \pm 0.366$ & 1.178 & 10 & $3.196 \pm 0.105$ & 1.167 \\
\hline $1 \times 8 \ldots$ & 11 & $2.845 \pm 0.338$ & 1.438 & 12 & $3.187 \pm 0.315$ & 1.201 \\
\hline $3 \times 6 \ldots \ldots \ldots \ldots \ldots \ldots$ & 13 & $2.982 \pm 0.446$ & 1.060 & 14 & $2.885 \pm 0.588$ & 1.173 \\
\hline $3 \times 8 \ldots \ldots \ldots \ldots \ldots \ldots$ & 15 & $2.824 \pm 0.509$ & 1.112 & 16 & $2.990 \pm 0.463$ & 1.097 \\
\hline $5 \times 2 \ldots \ldots \ldots \ldots \ldots \ldots$ & 17 & $2.911 \pm 0.506$ & 1.311 & 18 & $2.863 \pm 0.447$ & 1.296 \\
\hline $7 \times 2 \ldots \ldots \ldots \ldots \ldots \ldots$ & 19 & $2.857 \pm 0.541$ & 1.261 & 20 & $2.895 \pm 0.688$ & 1.236 \\
\hline
\end{tabular}

in all of the cases and hence a sex difference may be suspected. This sex difference is made up of a difference in favor of the males with respect to leg length and one in favor of the females with respect to pectoralis. The net result here is a small difference favoring the females, with the borderline odds on significance of 25 to 1 .

The value of the coefficient of correlation between the $k$ values for the pectoralis-major-body-weight relation and $k$ for the leg-length-bodyweight was found to be $0.172 \pm 0.217$. The coefficients of correlation of the same pectoralis-major value of $k$ and the $k$ 's for femur, tibiotarsus, and tarsometatarsus were respectively $0.200 \pm 0.215,0.214 \pm 0.213$, and $0.216 \pm 0.213$. Obviously, none of these coefficients of correlation are significant.

As far as the lack of significance of these correlations is concerned, 
two possible interpretations present themselves. One is that the growth of the pectoralis major is controlled by other factors than those governing the growth of the leg bones. The other lies in the fact that no real differences exist between any of the $k$ values for the leg or any of the $t_{i}$ values for the pectoralis major. Consequently it may be argued that no correlation is to be expected whether or not the factors controlling growth are the same in both structures.

\section{COMPARISON WITH OTHER BREEDS}

The data presented in the preceding sections point very definitely to the fact that the $k$ values for the structures investigated in the two breeds studied are the same. The fact that the various hybrids are also similar to the parental breeds in their heterogony constants would suggest that the genetic factors controlling auxano-differentiation are identical in the Plymouth Rock and the Minorea. There does not seem to be any escape from such a conclusion, and the first question which brings itself to mind is whether or not the reason for this lies in the similar adult weights of the two breeds. In order to investigate this point, an attempt was made to compare the values obtained here with breeds of other defined adult weights than that of the Plymouth Rock and the Minorca.

Unfortunately there is a distinct paucity of published material which could be used for this purpose. Measurements of bone length are available in a number of cases, but they are recorded either as averages or without corresponding body weights (Schneider and Dunn, 1924 ; Dunn, 1928; Hutt, 1929).

A. J. G. Maw was kind enough to supply the writer with individual records of body weights and tarsometatarsus lengths of birds used in his Brahma $\times$ Sebright crosses. However, all of the observations were made on adult birds and because of that were found not to be amenable to the proposed analysis. Female fowls, particularly of the heavier breeds, have a tendency for a differential degree of fat deposition with increasing age. Consequently the body weights in Maw's data showed a considerable scatter when bone length was used as the second coördinate. No close correspondence was found between body weight and the length of tarsometatarsus, and no reliable $k$ values could be calculated.

It was felt, however, that some degree of comparison could be made by using the averages presented by Maw and by other investigators. Such data were found in the report of Kopec (1927) on Leghorns, Orpingtons, and hybrids between them; and in that of Lerner and Asmundson (1932) on Light Sussex $\times$ Ancona hybrids. The latter workers present only measurements of tarsometatarsi of females, and hence the other 
figures used were confined to that structure. In order to have comparable figures, the Plymouth Rock and Minorca females within the weight range of the adult Bantams used in this investigation (see next section) were singled out of the total population used in the present study. The logarithms of average tarsometatarsus length were then plotted against the logarithms of the average body weight. The resultant plot is presented in figure 3. This figure includes data for jungle fowl and also for Bantams,

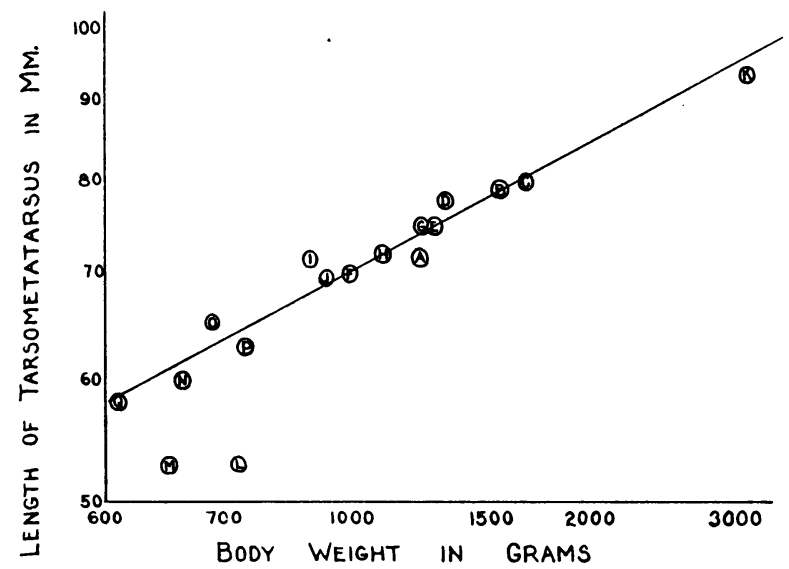

Fig. 3.-Length of the tarsometatarsus of females of different species, breeds, and crosses, plotted against body weight on a log grid. $A$, White Leghorn; $B$, Black Orpington; $C, D, E$, crosses of White Leghorn and Black Orpington ; $F, G, H$, crosses of Light Sussex and Ancona ; $I$, Black Minorea; $J$, Barred Plymouth Rock; $K$, Light Brahma; $L$, Bantam; $M$, Sebright Bantam; $N$, Gallus gallus ; $O$, Gallus lafayetti; $P$, Gallus sonnerati; $Q$, Gallus varius ( $A$ to $E$ from Kopeć, $1927 ; F$ to $H$, from Lerner and Asmundson, $1932 ; I, J, L$ from this paper; $K$ from Maw, private communication ; $M$ from Maw, $1935 ; N$ to $Q$ from Beebe, 1921.)

to which reference will be made later. The jungle fowl represented are the extant wild species of fowl, which have probably contributed to the ancestry of the domestic chickens; these are described in detail by Beebe (1921), who recorded body weights and tarsal measurements of four species, Gallus gallus, G. lafayetti, G. sonnerati, and G. varius.

The most interesting observation which can be made from this figure is that apparently the jungle fowl and all of the breeds studied except the Bantams fall into a relation which approaches a straight line. This strongly suggests that the $k$ value is closeily similar in these breeds. It has been shown in preceding sections that the $k$ value is similar for both the pectoralis major and the leg bones in the case of the Plymouth Rocks 
and the Minorcas. If this can be established for other breeds as well, it may seem that the general growth pattern is the same in the normal-sized breeds of fowl. This points to the hypothesis that a basic genetic complex for size interrelation of parts exists in the fowl, which does not necessarily have a bearing on the ultimate size. The latter may be controlled by different modifying factors. This hypothesis, however, would not include the case of the Bantams, since special conditions seem to prevail with them.

\section{BANTAM DATA}

Size Inheritance in Bantams.-In most of the work previously cited dealing with the size of the $F_{1}$ generation with respect to the size of the parents in the domestic fowl the hybrid generation was found to be closer in weight to the heavier parent. Notable exceptions are seen in cases where Bantams were used as one of the parents, such as in the work of Sokolov (1926), Danforth (1929), Jull and Quinn (1931), and Maw (1935).

Sokolov suggests dominance of Bantams for size. Danforth, in crosses of Bantams with bigger breeds, obtained $\mathrm{F}_{1}$ 's either intermediate or approaching the Bantam in size. Jull and Quinn, crossing Barred Plymouth Rocks with Rose Comb Black Bantams, found the $\mathrm{F}_{1}$ generation to be closer to the Bantam weight than to that of the Plymouth Rock. Similarly, Maw (1935) in a Light Brahma $\times$ Golden Sebright Bantam cross, found the hybrids to be smaller than the mean parental size.

Using measurements of bone length as a criterion, Maw observed that the difference in size between the two parents was due to some extent to a sex-linked factor. Not only was there a difference between reciprocalcross females, but a study of the $\mathrm{F}_{2}$ population revealed indications of linkage of size with two of the gene markers located on the sex chromosome, which were present in his stock.

These results are of great significance, not only because they constitute the first definite confirmation of Mendelian inheritance of size in poultry, but also because they indicate the presence of a size-limiting factor in Bantams, which may be dominant in nature. It should be noted, however, that while this may explain the results of Jull and Quinn (1931), it fails to fit the evidence of Punnett and Bailey (1914), who also worked with Bantams. In their case a cross of Gold-pencilled Hamburgs was made with Silver Sebright Bantams, and the hybrid population, while intermediate in weight, approached the Hamburg more closely than the Sebright. However, the Hamburg itself is not a very large breed, and the difference between it and the Sebright is not nearly so great as between the breeds used by Jull and Quinn or by Maw. Asmundson found that in

\footnotetext{
${ }^{6}$ Asmundson, V. S., private communication, January, 1936.
} 
crosses of Leghorn males with Bantam females, the crossbred females were exactly intermediate in body weight. The cross was made only one way and it is not possible to say whether or not the sex-linked factor operated, particularly since the data on males were somewhat limited.

If the Bantams possess a major size-inhibiting factor, its influence might be shown on the relative rates of growth of parts. Since differential rates exist in the various structures, the effect of a general growthretarding factor may be different on the different parts. Because of this

TABLE 8

Relative Growth Constants of Bantams

\begin{tabular}{|c|c|c|c|}
\hline Base & Part & $k$ or $k_{1}$ & $\log a$ \\
\hline & Pectoralis-major weight. . & $1.068 \pm 0.237$ & 1.391 \\
\hline With respect & Leg length.......... & $0.246 \pm 0.134$ & 2.263 \\
\hline & Femur length...... & $0.237 \pm 0.145$ & 1.748 \\
\hline \multirow[t]{2}{*}{ body weight } & Tibiotarsus length.. & $0.231 \pm 0.145$ & 1.889 \\
\hline & Tarsometatarsus length. & $0.279 \pm 0.164$ & 1.699 \\
\hline With respect & Femur length. . & $0.932 \pm 0.281$ & 1.748 \\
\hline to & Tibiotarsus length.. & $0.926 \pm 0.214$ & 1.889 \\
\hline \multirow[t]{2}{*}{ leg length } & Tarsometatarsus length. & $1.111 \pm 0.297$ & 1.699 \\
\hline & Pectoralis-major weight. & $3.372 \pm 1.926$ & 1.391 \\
\hline
\end{tabular}

situation, information on the heterogonic relation in the Bantams was thought to be of value.

Heterogony in Bantams. - Consequently extra series of dissections were made, for which 26 miscellaneous Bantams were available. The Bantam series comprised 23 females, mostly of the Buff Cochin breed, but with representatives of the Black Cochin, nonfrizzling segregates of a golden-laced Frizzle variety, a single-comb segregate of the White Wyandotte Bantam, and a number of unidentified types of intra-Bantam crosses. The 3 remaining individuals were males, 2 of which were also crossbred Bantams, the third being a Buff Cochin.

Dissections were performed on these birds, the same procedure as for normal-sized birds being followed. In the computations, all of the Bantams were treated together although, because of the heterogeneity of the population, great variability in the measurements taken ensued. The weight range represented was from 205 to 1,320 grams. The constants of heterogonic growth for these individuals are shown in table 8 .

The first striking point that may be noted from the $k$ values for the Bantams is that all of the leg bones are hypogonic, with respect to body weight, whereas in the case of the other breeds reported on (tables 3 and 
4), definite hypergony was indicated. In the case of the pectoralis major, the Bantams show approximate isogony. Because of the fact that 20 of the 26 birds used for these calculations were full-grown and hence the range of true measurements was limited, the only reliable $k$ value obtained is that for the pectoralis major. However, a possible interpretation is that the factors retarding the general growth also inhibited the growth of the pectoralis major and of the leg bones. This retardation was greater for these structures than for the whole of the body and consequently there must be some other organs in the Bantam compensating for this increased effect. It should be noted that the growth gradients in the leg observed in the Plymouth Rock and the Minorea cannot be demonstrated here. However, the high standard errors invalidate any possible deductions from this fact.

For figure 3 the averages of the 17 adult Bantam females were used. It may be seen that at least as far as the tarsometatarsus is concerned, the Bantams are distinctly out of line. This would indicate that either the Bantam has additional factors changing heterogonic relations or that this is the effect of the general growth-retarding factor. Which of the two interpretations is correct can be established by crosses of Bantams with normal-sized breeds. It is not possible to judge a priori the outcome of such a test, especially when it is remembered that Bantam breeds have undergone selection to duplicate the shape of their normal-sized counterparts. When a structure shows any condition except isogony, the arithmetic proportion of it to the whole, or the relation apparent to the eye is different at different body weights. Then selection of birds smaller in size but of the same proportions as a larger bird will lead per se to selection for differential heterogony constants. However, under the circumstances of the case on hand, since the pectoralis major grows faster than the whole of the body, one would expect that the Bantam would show increased hypergony to duplicate the final relation in the normal-sized fowl at a lower weight. As far as the tarsometatarsus is concerned, while it shows hypergony, the fact that it is a linear measure which is being compared to a mass one may possibly invalidate the reasoning.

The results presented are of interest because they have a definite bearing on theories concerning the rôle of mutations of size factors on evolution of form. The work of Robb on the equine skull may be introduced here before discussion of the application of the above data to the subject. Robb (1935) studied the development of facial proportions in a series of specimens of fossil Equidae. He concluded on the basis of his analysis that the changes in skull form observed from the Eocene Hyracotherium to the modern horse may be best explained on the basis of mutations 
arising which affect general body size, rather than mutations affecting form as such. This would probably mean that if a general uniform morphogenetic ground plan of growth exists for chickens, any mutation affecting total body size may find an expression in the rates of growth along the various growth gradient axes.

Castle (1932c) has expressed a somewhat similar idea; he states that change in proportions may be due not to orthogenetic tendencies, but as a consequence of changed body size. The genes here are genes controlling rates; these rates may vary with the position of the structures or tissues studied in the developing organism, but, in producing a harmonious whole, they are related to each other in most of the cases. Any change affecting factors governing the sum total of these rates may find a differential expression in each constituent rate. Thus, in the case of the breeds of domestic fowl, it has been shown that a uniformity in the rate of development of the long bones of the leg and of the pectoralis major exists in the Minorca and the Plymouth Rock, yet an indication is present that the Bantams show a distinctive rate.

\section{RELATIVE GROWTH AND HEREDITARY SIZE LIMITATION}

The phylogeny of most of the breeds of chickens involved is lost in antiquity. Robinson (1924) states that Bantams were known from immemorial times, but that they were probably somewhat larger than at present until continuous selection by man brought them down to the present size. Aldrovandi (1637), who compiled one of the earliest complete descriptive works that included poultry, mentions Aristotle's description of the Hadrian fowls, which probably represents the earliest record of dwarf or Bantam poultry. The actual origin of these remains obscure, so that in reality no information is at hand as to the phylogenetic relation of the Bantams to normal-sized fowls.

It is quite conceivable that all of the domestic poultry originally had a uniform genetic complex controlling total body size and thus the rates of auxano-differentiation of different structures. Sometime in the phylogeny of the fowl, a basic mutation or a series of such took place and as a result of selection of the extreme mutant forms, the modern Bantam was produced. The growth patterns of the other breeds may, however, be controlled by basic factors for size limitation which are common to all of them, while modifiers may account for total size differences. In addition to these same factors, the Bantam possesses dominant or partially dominant factors which reduce its size further. This hypothesis seems to fit most of the facts of the case and can help in the interpretation of the uncertain results obtained in crosses between breeds, other than 
Bantams. The difference in size between the larger and the smaller of our normal breeds may well depend on a very large number of modifiers of the basic size-limiting factors and hence the $\mathrm{F}_{2}$ population required to demonstrate this would probably be above the limits of practical experimentation.

An interesting parallel to these ideas lies in the study of evolutionary relative growth in the titanotheres by Hersh (1934). He has found that various heterogonic constants of skeletal structures of a number of Eocene and Oligocene genera of titanotheres differed from each other. At the same time ascending species within the genus showed no change in either $b$ or $k$. The evolution of titanotheres in size is interpreted by Hersh as a result of incorporation in the stock of mutant genes bringing about an increased number of cell divisions. The coefficient of heterogonic growth was the factor indicating the partition of this greater number of divisions in different directions, and since it differed in various organs and structures, a change in proportions followed.

It is evident that a similar line of reasoning may be applied to the gallinaceous species. However, the case of the Bantam, which is classified as belonging to the species Gallus domesticus together with the other breeds, affords an extension of the principle not only within a genus, but within a species. A change in the heterogony constants is suggested here, and since by no stretch of imagination can the Bantam be placed as a taxonomically separate species from other domesticated breeds of poultry (though in nature morphological isolation would exist between Bantams and, for instance, Brahmas, because of the disparity in size), it must be concluded that differences in heterogony constants may be present in coexisting varieties of one and the same species.

Additional evidence for a difference in the genetic complex of factors controlling growth and development between Bantams and other breeds is found in the work of Promptoff (1928). In studying structural types of the dorsosacrum he reported that most of the breeds are possessed of four or five dorsosacral vertebrae, but that the Bantam has only three. The mode of inheritance of the character was not clearly described by Promptoff, since only a small number of individuals were available. However, a general growth-retarding factor may be easily conceived to be responsible for the difference found. A parallel suggestion is made by Sawin (1935) to account for the variability in number of ribs and vertebrae in the skeleton of the rabbit.

The time of action of the growth-retarding factor can be estimated in the ontogeny of the Bantam to lie at the time of active histo-differentiation of the dorsosacrum, which is concurrent with differentiation of the 
posterior limb bud. It may once more be recalled that Danforth (1932) produced rumpless fowls by fluctuating incubator temperature in the first week of incubation. A hereditary factor may be involved with a parallel effect in the case of the Bantam. It is, of course, quite possible that the mutation involved is one of the type described by Haldane (1932), which affects the time of action of a gene. Changes in the value of $b$ would particularly fall into this class, though $k$ values may also be affected. Stockard's interpretation of the genetic bases for achondroplasia (1932) may be viewed in the same light.

An interesting case of a change in the value of $b$ without a change in $k$ is found in chubby Drosophila. Dobzhansky and Duncan (1933) plotted body length against body width on a double logarithmic scale for the larvae of wild-type Drosophila and of the mutant chubby type, which exhibits a different shape than the normal. They found the slope to be the same in the two instances but a distinct difference may be noted in the intercept on the plot they present. Here, the mutation exhibited in an early developmental stage does not affect the rate of a process, but its time of onset. Such interpretation approaches Hersh's (1934) application of Brandt's (1928) "Typologisches Grundprinzip" to his discussion of the case of the titanotheres.

A question of interest is brought up by Kaiser (1935) in his study of factors governing shape and size in the fruits of peppers. He extends the concept of Ford and Huxley (1927), who conclude that a defined rate of relative growth is inherited, by stating that developmental genes govern not merely growth velocities but the relation between these velocities. This is somewhat similar to Sinnott's conception of the size and shape differences in gourds (1935c). Here the smaller race is essentially like an early developmental stage of the larger one, the shape difference being due to the effect of size.

Parallel reasoning cannot be applied successfully to the instance of the fowl at this time. It is true that in the different normal-sized breeds, which in their zygotic state carry factors defining ultimate weight, similar factors for the relative rate of growth of both the pectoralis major and the leg bones are present. In the case of the Bantam the proportionate growth rates of parts are changed concurrently with the change in size. Yet the Bantam, as shown in figure 3, is obviously not representative of the earlier stages of growth of the normal-sized breeds.

The test of Kaiser's dictum regarding the interrelation of the growth rates of parts would come in the crosses of Bantams with the larger breeds. Such crosses should be of considerable interest and should yield valuable information on this and other points. A limited number of ob- 
servations are already available and further work along these lines will be undertaken.

\section{SUMMARY}

Investigations of heterogonic growth relations reveal that the growth of the pectoralis major of the leg bones in relation to the growth of the entire organism follows a similar course in the Plymouth Rock and the Minorca breeds of fowl. Hybrids between these two breeds including first-generation crosses as well as backcrosses of these to both parents, possess the same pattern of growth of the structures studied as the parents. Sex differences are noted in the values of the coefficient of heterogonic growth, with the females showing a higher value for the pectoralis major with respect to body weight and a lower value for the leg length with respect to body weight than the males.

Comparison of the data presented with the material of other investigators suggests the hypothesis that the basic genetic complex for the type of growth of parts with respect to the growth of the whole is common to the different breeds of poultry with the exception of the Bantams. The Bantams, a number of which are also included in this study, show a type of heterogony possibly different from that observed in the larger-sized breeds. While in the latter hypergony was indicated both for the muscle investigated and for the leg bones, in the Bantam hypogony was present in the leg bones, with an approximation to isogony in the muscle. It is thus suggested that the Bantams probably possess growth-retarding factors which affect not only total body size but also the relative rate of growth of the parts studied.

Growth gradients based on length measurements were observed in the posterior limb, with the distal bone (tarsometatarsus) growing at a more rapid rate in relation to the rate of body growth, the median bone (tibiotarsus) presenting an intermediate rate of growth, and the proximal bone (femur) the slowest.

\section{ACKNOWLEDGMENTS}

The writer wishes to express his appreciation to Dr. L. W. Taylor for his kind guidance and advice; and to Dr. V. S. Asmundson for his critical interest and encouragement throughout the investigation. An acknowledgment is also due to Mr. H. B. Mugglestone for contributing so generously of his time and experience in connection with some phases of the problem. 


\section{LITERATURE CITED}

Aldrovandi, U.

1637. Ornithologiae. Vol. 2. 862 p. N. Tibaldinum, Bonon.

American Poultry Association.

1930. American standard of perfection. 487 p. American Poultry Assoc., St. Paul. ASMUNDSON, V. S., and I. M. LERNER.

1933. Inheritance of rate of growth in domestic fowl. II. Poultry Sci. 12:250-55.

1934. Inheritance of rate of growth in domestic fowl. III. Poultry Sei. 13:348-52.

Axelsson, $J$.

1933. Variation and heredity of some characters in White Leghorns, Rhode Island Reds, and Barnevelders. II. Lunds Univ. Årsskr. n.s. Sec. 2, 29(No. 1) :1-71.

BEEBE, W.

1921. A monograph of the pheasants. Vol. 2. 269 p. H. F. and G. Witherby, London. BlunN, C. T., and P. W. Gregory.

1935. The embryological basis of size inheritance in the chicken. Jour. Exp. Zool. $70: 397-414$.

BRANDT, W.

1928. Das typologische Grundprinzip. Arch. Entwickl. Mech. Organ. 114:54-64.

BRIDGES, C. B., and E. Gabritschevsky.

1928. The giant mutation in Drosophila melanogaster. Ztschr. Induktive Abstam. u. Vererbungslehre 46:231-47.

Brody, S.

1926. Growth and development. I. Missouri Agr. Exp. Sta. Research Bul. 96:3-182.

BROOKE, H. C.

1926. Hairless mice. Jour. Heredity. $17: 173-74$.

Brown, E.

1906. Races of domestic poultry. 234 p. Edw. Arnold, London.

Byerly, T. C.

1930. The effects of breed on the growth of the chick embryo. Jour. Morphol. and Physiol. 50:341-59.

Castle, W. E.

1909. Studies of inheritance in rabbits. Carnegie Inst. Wash. Pub. 114:1-70.

1914. Size inheritance and the pure line theory. Ztschr. Induktive Abstam. u. Vererbungslehre 12:225-37.

1916. Studies on inheritance of guinea pigs and rats. I. Carnegie Inst. Wash. Pub. 241:1-55.

1922. Genetic studies of rabbits and rats. Carnegie Inst. Wash. Pub. 320:1-55.

1924a. Does the inheritance of difference in general size depend upon general or special size factors? Natl. Acad. Sci. Proc. 10:19-22.

$1924 b$. Are the various parts of the body genetically independent in size? Natl. Acad. Sci. Proc. 10:181-82.

1925. Heredity in rabbits and guinea pigs. Bibliog. Genet. 1:419-58.

1926. Comment on Dr. Mjoen's paper. Jour. Heredity 17:182-83.

1929. A further study of size inheritance in rabbits, with special reference to the existence of genes for size characters. Jour. Exp. Zool. 53:421-54.

1930. Race mixture and physical disharmonies. Science 71:603-6. 
Castle, W. E. (Continued)

1931. Size inheritance in rabbits; the backcross to the large parent race. Jour. Exp. Zool. 60:325-38.

1932a. Green's studies of linkage in size inheritance. Amer. Nat. 66:82-87.

1932b. Growth rates and racial size in rabbits and birds. Science 76:259-60.

1932c. Body size and body proportions in relation to growth rates and natural selection. Science 76:365-66.

1933a. The gene theory in relation to blending inheritance. Natl. Acad. Sci. Proc. 19:1011-15.

1933b. The incompleteness of our knowledge of heredity in mammals. Jour. Mammal. 14:183-88.

1934a. Body size of reciprocal hybrids in rabbit crosses. Natl. Acad. Sci. Proc. $20: 621-25$.

1934b. Size inheritance in rabbits; further data on the backeross to the small race. Jour. Exp. Zool. 67:105-13.

Castle, W. E., W. H. Gates, and S. C. Reed.

1936. Studies of a size cross in mice. Genetics 21:66-78.

CAstle, W. E., and P. W. GREgory.

1929. The embryological basis of size inheritance in the rabbit. Jour. Morphol. Physiol. 48:81-103.

1931. The effects of breed on growth of the embryo in fowls and rabbits. Science $73: 680-81$.

Chesley, P.

1932. Lethal action in the short-tailed mutation in the house mouse. Soc. Exp. Biol. and Med. Proc. 29:437-38.

1935. Development of the short-tailed mutant in the house mouse. Jour. Exp. Zool. 70:429-59.

Clarke, A. E.

1931. Inheritance of the dwarf branching habit in sweet clover. Sci. Agr. 11: 326-32.

CoFfman, F. A.

1933. Heterosis: specific not general in nature. Science 77:114-15.

Crane, M. B., and W. J. C. Lawrence.

1933. Genetical studies in cultivated apples. Jour. Genetics. 28:265-96.

CREW, F. A. E.

1923. The significance of an achondroplasia-like condition met with in cattle. Roy. Soc. [London] Proc. Series B. 95:228-55.

Cúñot, L.

1928. Génétique des souris. Bibliog. Genet. 4:179-242.

Currence, T. M.

1932. Genetic association between qualitative and quantitative characters in the tomato. 6th Internatl. Cong. Genetics Proe. 2:32-34.

DALE, E. E.

1928. Inheritance of fruit length in Capsicum. Mich. Acad. Sci., Arts, and Letters, Papers 9:89-110.

DANFORTH, C. H.

1929. Bantam genetics. Jour. Heredity 20:573-82.

1932. Artificial and hereditary suppression of sacral vertebrae in the fowl. Soc. Exp. Biol. and Med. Proc. 30:143-45. 


\section{DAVENPORT, C. B.}

1917. Inheritance of stature. Genetics 2:313-89.

1924. Body build and its inheritance. Carnegie Inst. Wash. Pub. 329:1-176.

DAVY, J. B.

1927. Persian and Merino sheep crosses. Jour. Heredity 18:25-32.

DaWES, B., and J. S. HuXLeY.

1934. Rapid growth rate and diminishing heterogony. Nature 133:982.

Detlefsen, J. A.

1914. Genetic studies on a cavy species cross. Carnegie Inst. Wash. Publ. 205: 1-134.

Dobrovolskaia-Zavadskaia, N., and N. KoboziefF.

1930. Sur le facteur lèthal accompagnant l'anourie et la brachyurie chez la souris. Compt. Rend. Acad. Sei. [Paris] 191:352-55.

\section{Dobzhansky, $\mathrm{T}$.}

1929. The influence of quantity and quality of chromosome material on the size of cells in Drosophila melanogaster. Arch. Entwickl. Mech. Organ. 115:363-76.

1934. Are racial and specific characters non-Mendelian? Jour. Mammal. 15:1-3.

Dobzhansky, T., and F. N. Duncan.

1933. Genes that affect early developmental stages of Drosophila melanogaster. Arch. Entwickl. Mech. Organ. 130:109-30.

Dubois, E.

1897. Sur le rapport du poids de l'encèphale avec la grandeur du corps chez les mammiféres. Bul. Soc. Anthropol. Paris (ser. 4) 8:337-76.

DUNN, L. C.

1925. Inheritance of rumplessness in domestic fowl. Jour. Heredity 16:127-34.

1928. The effect of inbreeding on the bones of the fowl. Connecticut (Storrs) Agr. Exp. Sta. Bul. 152:53-112.

EckLEs, C. H., and W. W. SwETT.

1918. Some factors influencing the rate of growth and the size of dairy heifers at maturity. Missouri Agr. Exp. Sta. Research Bul. 31:3-56.

Elders, A. T.

1928. A dwarfing character in sweet clover. Sci. Agr. 8:438-40.

EMERSON, R. A.

1910. The inheritance of sizes and shapes in plants. Amer. Nat. 44:739-46.

EMERson, R. A., and E. M. EAST.

1913. The inheritance of quantitative characters in maize. Nebraska Agr. Exp. Sta. Research Bul. 2:1-20.

Ephrussi, B.

1933. Sur le facteur lèthal des souris brachyures. Compt. Rend. Acad. Sci. [Paris] 197:96-98.

FeLdman, H. W.

1935. The brown variation and growth of the house mouse. Amer. Nat. 69:370-74.

Feldstein, M. J., and A. H. Hersh.

1935a. The determination of genetic constants of relative growth. Amer. Nat. 69: . 344-53.

1935b. The calculation of relative growth constants. Amer. Nat. 69:610--13.

FELL, H. B., and W. LANDAUER.

1935. Experiments on skeletal growth and development in vitro in relation to the problem of avian phokomelia. Roy. Soc. [London] Proc. Series B. 118: 133-54. 
Ford, E. B., and J. S. HuXLey.

1927. Mendelian genes and rates of development in Gammarus chevreuxi. Brit. Jour. Exp. Biol. 5:112-34.

Freeman, G. F.

1919. The heredity of quantitative characters in wheat. Genetics 4:1-93.

Frets, G. P., and G. Wanrooy.

1934. Die Erblichkeit der Bohnenform und des Bohnengewichts bei Phaseolus vulgaris. II. Genetica [The Hague] 16:297-314.

1935. Die Erblichkeit der Bohnenform und des Bohnengewichts bei Phaseolus vulgaris. III. Genetica [The Hague] 17:47-89.

Frost, H. B.

1923. Heterosis and dominance of size factors in Raphanus. Geneties 8:116-53.

GHIGI, A.

1909. Ricerehe di sistematica sperimentali sul genere Gennaeus wagler. p. 38. Bologna [Cited by Phillips, 1912].

Ghigi, A., and A. TAIBell.

1927. Results of some crosses between table and egg breeds. 3rd World's Poultry Congress Proc. p. 126-29.

GoLDSCHMIDT, R.

1913. Zuchtversuche mit Enten. I. Ztschr. Induktive Abstam. u. Vererbungslehre 9:161-91.

1927. Physiologische Theorie der Vererbung. 247 p. J. Springer, Berlin.

GREen, C. V.

1930. Inheritance in a mouse species cross. Amer. Nat. 64:540-44.

1931a. On the nature of size factors in mice. Amer. Nat. 65:406-16.

1931b. Linkage in size inheritance. Amer. Nat. 65:502-11.

1931c. Size inheritance and growth in a mouse species cross (Mus musculus $\times$ Mus bactrianus) III. Jour. Exp. Zool. 59:213-45.

1931d. Size inheritance and growth in a mouse species cross (Mus musculus $\times$ Mus bactrianus) IV. Jour. Exp. Zool. 59:247-63.

1932a. Genetic linkage in size inheritance-a reply. Amer. Nat. 66:87-91.

1932b. An evaluation of size genes. Amer. Nat. 66:566-68.

1932c. A genetic craniometric study of two species of mice and their hybrids. Jour. Exp. Zool. 63:533-51.

1932d. Inheritance of weight in a mouse interspecific cross. 6th Internatl. Cong. Genetics Proc. 2:71.

1933a. Inheritance of foot length in a mouse species cross. Jour. Heredity 21: $440-42$.

1933b. Differential growth in the crania of mature mice. Jour. Mammal. 14:122-31.

1934. An analysis of size genes. Amer. Nat. 68:275-78.

1935a. Quantitative characters in reciprocal hybrids. Amer. Nat. 69:278-82.

1935b. The association between color and size in mice. Amer. Nat. 69:635-38.

Green, C. V., and E. Fekete.

1933. Differential growth in the mouse. Jour. Exp. Zool. 66;351-70.

Greene, H. S. N., C. K. Hu, and W. H. Brown.

1934. A lethal dwarf mutation in the rabbit with stigmata of endocrine abnormality. Science 79:487-88. 
GREGORX, P. W.

1933. The nature of size factors in domestic breeds of cattle. Genetics 18:221-49.

Gregory, P. W., and W. E. CAstLe.

1931. Further studies on the embryological basis of size inheritance in the rabbit. Jour. Exp. Zool. 59:199-211.

GREgory, P. W., and H. Goss.

$1933 a$. The relation of sulphydryl concentration to size inheritance in the rabbit. Amer. Nat. 67:180-85.

1933b. Glutathione concentration and hereditary body size. II. Jour. Exp. Zool. $66: 155-73$.

1933c. Glutathione concentration and hereditary body size. III. Jour. Exp. Zool. $66: 335-49$.

Gregory, P. W., H. Goss, and V. S. Asmundson.

1935. Glutathione concentration of White Leghorn and Barred Plymouth Rock embryos after fourteen days of incubation. Soc. Exp. Biol. and Med. Proc. $32: 966-67$.

HAAN, H. DE.

1927. Length factors in Pisum. Geneties 9:481-98.

HaLdane, J. B. S.

1932. The time of action of the gene, and its bearing on some evolutionary problems. Amer. Nat. 66:5-24.

HAMMOND, J.

1920. On the relative growth and development of various breeds and crosses of cattle. Jour. Agr. Sei. [England] 10:233-90.

1921. On the relative growth and development of various breeds and crosses of sheep. Jour. Agr. Sci. [England] 11:367-407.

1922. On the relative growth and development of various breeds and crosses of pigs. Jour. Agr. Sci. [England] 12:387-423.

HARLAND, S. C.

1934. Further experiments on the inheritance of the crinkled dwarf mutant of G. barbadense. Jour. Genetics 28:315-25.

HERSH, A. H.

1931. Facet number and genetic growth constants in bar-eyed stocks of Drosophila. Jour. Exp. Zool. 60:213-48.

1934. Evolutionary relative growth in the titanotheres. Amer. Nat. 68:537-61.

Hopkins, J. W., and J. Biely.

1935. Variation in weight of some internal organs of the domestic fowl (Gallus gallus). Canad. Jour. Research 12:651-56.

Houghtaling, H.

1935. A developmental analysis of size and shape in tomato fruit. Bul. Torrey Bot. Club 62:243-52.

Hunt, H. R., R. Mixter, and D. Permar.

1933. Flexed tail in the mouse, Mus musculus. Genetics 18:355-66.

HuTT, F. B.

1929. Sex dimorphism and variability in the appendicular skeleton of the Leghorn fowl. Poultry Sci. 8:202-18.

HuxLeY, J. S.

1924. Constant differential growth-ratios and their significance. Nature [London] 114:895-96.

1932. Problems of relative growth. 276 p. Methuen and Co., London. 
JuLL, M. A., and J. P. QuinN.

1931. The inheritance of body weight in the domestic fowl. Jour. Heredity 22: 283-94.

KAISER, S.

1935. The factors governing shape and size in Capsicum fruits; a genetic and developmental analysis. Bul. Torrey Bot. Club 62:433-54.

KAMENOFF, R. J.

1935. Effects of the flexed-tail gene on the development of the house mouse. Jour. Morph. 58:117-55.

KAUFMAN, L.

1927. Recherches sur la croissance du corps et des organes du pigeon. Biol. Generalis 3:105-28.

1929. Les différences du taux d'accroissement des oiseaux sont-elles manifestes pendant la vie embryonnaire? Arch. Anat. Micr. 25:327-35.

1930a. Badania nad pochodzeniem róznic wielkości ciala, wraz z opisem nowej metody kultur in vitro jaj kur i golębi. [Phenogenesis of the differences of body size, partly based on a new method of invitro cultures of fowl and pigeon eggs.] Acta Biol. Exp. [Warsaw] 5:33-46.

1930b. Innere und äussere Wachstumfaktoren. Untersuchungen an Hühnern und Tauben. Arch. Entwickl. Mech. Organ. 122:395-431.

Keeble, F., and C. Pellew.

1910. The mode of inheritance of stature and time of flowering in peas. Jour. Genetics 1:47-56.

KELLER, C.

1933. Vergleichende Zellen und Kernmessungen bei grossen und kleinen Hühnerrassen zur Prüfung der genetisch bedingten Wuchsunterschiede. Zugleich ein Beitrag zur Frage des rhythmischen Wachstums der Kerne. Ztschr. KEMP, $T$ T. Zellforsch. Mikros. Anat. 19:510-36.

1933. Hereditary dwarfism in the mouse. Acta Pathol. Scand. Suppl.-bd. 16: 189-93.

KIsLovsKri, D. A.

1928. Naked-a recessive mutation in the rabbit. Jour. Heredity 19:438-39.

KLODNITZKY, L., and G. SPETT.

1925. Kürzschwanzige und schwanzlose Varianten bei Hunden. Ztschr. Induktive Abstam. u. Vererbungslehre 38:72-74.

КовоZIEFr, $\mathrm{N}$.

1934. La léthalité des souris anoures et brachyures, statistique des embryons abortifs. Compt. Rend. Acad. Sei. [Paris] 198:617.

Koch, F. E., and V. K. DymaN.

1934. Data on weight of body parts of battery chickens. Poultry Res. Inst. U.S.S.R. Trans. 2(1):3-7.

KONDYREV, L. V.

1928. [Results of crossing of a small and a large breed of chickens.] (Translated title.) Vsesoiuznyi S'ezd Zoologov, Anatomov i Gistologov. Trudy 3:420-21.

KOPEČ, S.

1924. Studies on the inheritance of weight of new born rabbits. Jour. Genetics 14:241-63. 
1927. Zur Kenntnis der Vererbung der Körperdimensionen und der Körperform beim Haushuhn. Ztschr. Induktive Abstam. u. Vererbungslehre 45:87-104.

KOPEČ, S., and M. LATYSZEWSKI.

1930. Further studies on the morphogenetical value of the weight of mammals at birth. Observations on mice. IV and V. Pam. Państ. Inst. Nauk. Gosp. Wiejsk. Pulawach (Mem. Inst. Natl. Polon. Econ. Rurale Pulawy 11: 299-334.

LAMBERT, W. V., and A. M. SCIUCHETTT.

1935. A dwarf mutation in the rat. Jour. Heredity 26:91-94.

LANDAUER, W.

1928. Morphology of intermediate rumplessness in the fowl. Jour. Heredity 19: 453-67.

1934. Studies on the Creeper fowl. VI. Connecticut (Storrs) Agr. Exp. Sta. Bul. 193:3-79.

Landauer, W., and L. C. Dunn.

1930. Studies on the Creeper fowl. I. Jour. Genetics 23:397-413.

LAPICQUE, L.

1898. Sur la relation du poids de l'encéphale au poids du corps. Compt. Rend. Soc. Biol. [Paris] 50:62-64.

LATIMER, H. B.

1924. Postnatal growth of the body, system and organs of the Single Comb White Leghorn chicken. Jour. Agr. Research 29:363-97.

1925. The relative postnatal growth of the systems and organs of the chicken. Anat. Rec. 31:233-53.

1927. Postnatal growth of the chicken skeleton. Amer. Jour. Anat. 40:2-57.

1932. Postnatal growth changes in the Single Comb White Leghorn chicken. Kansas Univ. Bul. 33:199-206.

Latimer, H. B., and C. T. Pedersen.

1923. The variability in the gross body weight and the weights of the liver, feathers and blood of 131 chickens. Poultry Sci. 3:1-10.

LAUTH, $\mathrm{H}$.

1935. Vererbung von Körper- und Eigewicht bei Haushuhnrassen. Ztschr. für Züchtung, Teil B 31:271-310.

Lebedinsky, N. G., and A. Dauvart.

1927. Atrichosis und ihre Vererbung bei der albinotischen Hausmaus. Biol. Zentbl. 47:748-52.

LERNER, I. M.

1936. Heterogony in the axial skeleton of the. Creeper fowl. Amer. Nat. 70:595-98.

LERNER, I. M., and V. S. A SMUNDSON.

1932. Inheritance of rate of growth in domestic fowl. I. Sci. Agr. 12:652-64.

LINDSTROM, E. W.

1928. Linkage of size, shape and color genes in Lycopersicum. Ztschr. Induktive Abstam. u. Vererbungslehre, Supplement band 2:1031-57.

1935. Segregation of quantitative genes in tetraploid tomato hybrids as evidence for dominance relations of size characters. Genetics 20:1-11.

LIVESAY, E. A.

1930. An experimental study of hybrid vigor or heterosis in rats. Genetics 15: 17-54. 
Lock, R. H.

1906. Studies in plant breeding in the tropies. III. Ann. Roy. Bot. Gard. Peradeniya. 3 pt. 2:95-184. [Cited by Phillips, 1912].

LOEFFLER, L.

1934. Über eine neue Form von Hypotrichosis (Hypotrichosis juvenilis) bei der weissen Hausmaus. Ztschr. Induktive Abstam. u. Vererbungslehre $67: 209-11$.

LUMER, H.

1936. The relation between $b$ and $k$ in systems of relative growth functions of the form $y=b x^{\mathrm{k}}$. Amer. Nat. 70:188-91.

MACDowell, E. C.

1914. Size inheritance in rabbits. Carnegie Inst. Wash. Pub. 196:1-55.

MARSHAK, A.

1936. Growth differences in reciprocal hybrids and cytoplasmic influence on growth in mice. Jour. Exp. Zool. 72:497-509.

Maw, A. J. G.

1935. The inheritance of skeletal dimensions in the domestic fowl. Sci. Agr. 16: 85-112.

MAY, H. G.

1925. The inheritance of body-weight in poultry. I. Rhode Island Agr. Exp. Sta. Bul. 200:4-34.

MAY, H. G., and N. F. WATERS.

1927. The inheritance of body-weight in the Brahma-Leghorn cross in the domestic fowl. 3rd World's Poultry Cong. Proc. p. 118-22.

MAYHEW, R. L., and C. W. UPP.

1932. Inherited (?) dwarfism in the fowl. Jour. Heredity 23:269-75.

Mitchell, H. H., L. E. CARD, and T. S. Hamilton.

1926. The growth of White Plymouth Rock chickens. Illinois Agr. Exp. Sta. Bul. 278:71-132.

1931. A technical study of the growth of White Leghorn chickens. Illinois Agr. Exp. Sta. Bul. 367:83-139.

Miyazawa, B.

1921. Hereditary behaviour of a dwarf form of barley in Japan. Jour. Genetics $11: 205-8$.

MJOEN, J. A.

1923. Harmonic and disharmonic race crossings. 2nd Internatl. Cong. Eugen. Proc. 2:41-61.

1926. Biological consequences of race crossing. Jour. Heredity 17:175-82.

MoHr, O. L.

1929. Letalfaktoren bei Haustieren. Ztschr. f. Züchtung, Teil B 4:105-25.

MoMent, G. B.

1933. The effects of rate of growth on the post-natal development of the white rat. Jour. Exp. Zool. 65:359-93.

MOORE, A. R.

1933. Is cleavage rate a function of the cytoplasm or of the nucleus? Jour. Exp. Biol. 10:230-36.

NeEdham, J.

1931. Chemical embryology. 3 vols. 2,021 p. Cambridge Univ. Press.

1934. Chemical heterogony and the ground plan of animal growth. Biol. Rev. 9:79-109. 
Nevalonnyi, M., and J. Podhradsky.

1930. Der Einfluss der Schilddrüse und des Thymus auf die Skeletbildung. Vĕstn. Céskosl. Akad. Zěmed. 6:1-5.

Nilsson-Ehle, H.

1909. Kreuzenuntersuchungen an Hafer und Weizen. Lunds Univ. Årsskr. n. s. Sec. 2, 5:1-122.

Painter, T. S.

1928. Cell size and body size in rabbits. Jour. Exp. Zool. 50:441-53.

PEASE, M. S.

1928. Experiments on the inheritance of weight in rabbits. Jour. Genetics 20: 261-309.

PÉzard, A.

1918. Le conditionnement physiologique des caractères sexuels secondaires chez les oiseaux. Bul. Biol. France et Belg. 52:1-76.

Phillips, J. C.

1912. Size inheritance in ducks. Jour. Exp. Zool. 12:369-80.

1914. A further study of size inheritance in ducks with observations on the sexratio of hybrid birds. Jour. Exp. Zool. 16:131-45.

Plattiner, E.

1911. Studies of brachydactyly in domesticated animals. Inaugural dissertation. $77 \mathrm{p}$. University of Bern. [Cited by Mayhew and Upp, 1932].

Promptoff, A. N.

1928. Inheritance of structural types of dorsosacrum of domestic poultry. Jour. Genetics 20:29-51.

Punnett, R. C., and P. G. Bailey.

1914. On inheritance of weight in poultry. Jour. Geneties 4:23-39.

1918. Genetic studies in rabbits. I. Jour. Genetics 8:1-25.

RABAUD, E.

1914. Sur une anomalie héréditaire des membres postérieurs chez la souris. Compt. Rend. Soc. Biol. [Paris] 77:411-12.

RAMIAH, $\mathrm{K}$.

1933. Inheritance of height of plants in rice (Oryza sativa L.) Indian Jour. Agr. Sci. 3:411-32.

Rasmusson, J.

1933. A contribution to the theory of quantitative character inheritance. Hereditas 18:245-61.

RENSCH, B.

1923. Über die Ursachen von Riesen und Zwergwuchs beim Haushuhn. Ztschr. Induktive Abstam. u. Vererbungslehre 31:268-86.

RICHARDS, O. W.

1935. Analysis of the constant differential growth ratio. Tortugas Lab. Papers $29: 173-83$.

RIDDLE, O.

1929. The inheritance of thyroid size and the establishment of thyroid races in ring doves. Amer. Nat. 63:385-409.

RitzmanN, E. C.

1923. Inheritance of size and conformation in sheep. New Hampshire Agr. Exp. Sta. Tech. Bul. 25:3-36. 
RoBB, R. C.

1929a. On the nature of hereditary size limitation. I. British Jour. Exp. Biol. $6: 293-310$.

1929b. On the nature of hereditary size limitation. II. British Jour. Exp. Biol. $6: 313-24$.

1935. A study of mutations in evolution. I. Jour. Genet. 31:39-46.

RoBINson, J. H.

1924. Popular breeds of domestic poultry. 352 p. Reliable Poultry Journal Pub. Co., Dayton, Ohio.

RULON, 0 .

1935. Differential reduction of Janus green during development of the chick. Protoplasma 24:346-64.

Rumiantzev, B.

1932. [On the question of group variability in rabbits.] (Translated title.) Bul. Lab. Genetics 9:235-42.

SAWIN, P. B.

1935. Inheritance of homeosis in the axial skeleton of the rabbit. [Abstract.] Records Geneties Soc. Amer. 4:79-80.

$\mathrm{SAX}, \mathrm{K}$.

1924. The nature of size inheritance. Natl. Acad. Sci. Proc. 10:224-27.

SCHKLJAR, N. M.

1935. Das Wachstum des Hühnerembryos in Abhängigkeit von verschiedenen Temperaturen und Feuchtigskeitsgraden im Brut-Apparat. Arch. Geff. $9: 213-23$.

SCHMALHAUSEN, I.

1931. Zur Methodik der Bestimmung der Wachstumskonstante. Arch. Entwickl. Mech. Organ. 124:82-92.

Schmalhausen, I., and J. Stepanowa.

1926. Studien über Wachstum und Differenzierung IV. Arch. Entwickl. Mech. Organ. 108:721-38.

SChMidt, J., E. LAUPRECht, and W. WINZENBURGer.

1934. Beiträge zur Vererbung der Mastleistungen des Sehweines. I. Züchtungskunde 9:4-23.

Schneider, M., and L. C. DunN.

1924. On the length and variability of the bones of the White Leghorn fowl. Anat. Rec. 27:229-39.

Schwangart, F., and H. Grau.

1931. Über Entformung, besonders die vererbbaren Schwanzmissbildungen bei der Hauskatze. Ztschr. Tierz. u. Züchtungs.-Biol. 22:203-49.

SIEGLINGER, J. B.

1933. A dwarf mutation in kafir. Jour. Heredity 24:337-38.

SinNoTT, E. W.

1931. The independence of genetic factors governing size and shape. Jour. Heredity 22:381-87.

1935a. Evidence for the existence of genes controlling shape. Genetics $20: 12-21$.

1935b. The histological basis of size differences in some cucurbit fruits. [Abstract.] Records Genetics Soc. Amer. 4:81-82.

1935c. A simple case of the effect of size difference on the expression of a shape genotype. [Abstract.] Records Genetics Soc. Amer. 4:82. 
Sinnotr, E. W., and L. C. Dunn.

1935. The effect of genes on the development of size and form. Biol. Rev. 10: 123-51.

SмITH, H. H.

1935. The relation between factors affecting color and size in certain species of Nicotiana. [Abstract.] Records Genetics Soc. Amer. 4:82-83.

SMith, P. E., and E. C. MACDowell.

1930. An hereditary anterior-pituitary deficiency in the mouse. Anat. Rec. $46: 249-57$.

1931. The differential effect of hereditary mouse dwarfism on the anterior-pituitary hormones. Anat. Rec. 50:85-93.

SNELL, G. D.

1929. Dwarf, a new Mendelian recessive character in the house mouse. Natl. Acad. Sci. Proc. 15:733-34.

1931. Inheritance in the house mouse, the linkage relations of short-ear, hairless and naked. Genetics 16:42-74.

SokoLov, M. R.

1926. [Genetics of the growth and size of fowls.] (Translated title.) Mem. Anikowo Genetic Sta. 1:100-101.

SolLas, I. B. J.

1909. Inheritance of colour and supernumerary mammae in guinea pigs, with a note on the occurrence of a dwarf form. Repts. Evol. Com. Roy. Soc. 5:51-79.

1914. Note on the offspring of a dwarf-bearing strain of guinea pigs. Jour. Genetics 3:201-4.

SoubA, A. J.

1923. Variation and correlation of organs of Single Comb White Leghorn cockerels. Anat. Rec. 26:291-96.

SPÖTTEL, W.

1932. Ein Beitrag zur Vererbung der Körperformen und des Skeletts. Züchtungskunde 7:296-308.

StANTON, T. R.

1923. Prolific and other dwarf oats. Jour. Heredity 14:301-5.

STOCKARD, C. $R$.

1921. Developmental rate and structural expression: An experimental study of twins, "double monsters" and single deformities and their interaction among embryonic organs during their origin and development. Amer. Jour. Anat. 28:115-277.

1932. The genetics of modified endocrine secretion and associated form patterns among dog breeds. 6th Internatl. Cong. Genetics Proc. 2:193-94.

SumNer, F. B.

1923. Studies of subspecific hybrids in Peromyscus. Natl. Acad. Sci. Proc. 9:47-52.

1924. The partial genetic independence in size of various parts of the body. Natl. Acad. Sci. Proc. 10:178-80.

SWetT, W. W., R. R. Graves, and F. W. Miller.

1928. Comparison of conformation, anatomy and skeletal structure of a highly specialized dairy cow, and a highly specialized beef cow. Jour. Agr. Research 37:685-717.

TINGEY, D. C.

1932. Inheritance of dwarfing in wheat. Utah Acad. Sci. Proc. 8:59-60. 
UPP, C. W.

1934. Further data on the inheritance of dwarfism in fowls. Poultry Sei. 13: 157-65.

Ve'TULANi, T.

1930. Experiments on the inheritance of body-weight and of some dimensions in new-born mice. Pam. Pánst Inst. Nauk. Gosp. Wiejsk. Pulawach (Mém. Inst. Natl. Polon. Écon. Rurale Pulawy) 11: [Cited by Kopeć and Latyszewski, 1930].

WARREN, D. C.

1930. Crossbred poultry. Kansas Agr. Exp. Sta. Bul. 252:1-54.

WATERS, N. F.

1931. Inheritance of body-weight in domestic fowl. Rhode Island Agr. Exp. Sta. Bul. 228:1-105.

1934. Growth and sexual maturity in Brahma and Leghorn fowl. Iowa Agr. Col. Jour. Sei. 8:367-84.

WeEtman, L. M.

1935. Inheritance and correlation of shape, size and color in the watermelon. [Abstract.] Records Genetic Soc. Amer. 4:87-88.

WeLlman, O.

1913. Köztelek [Budapest] 23(97) [Cited by Hammond, 1922.]

1916. Kreuzungsversuche mit kurzhaarigen, schwarzbrannen Dachshund und kurzhaarigen Foxterrier. Allatani Közlemenyek [Budapest]. [Cited by Rumiantzev, 1932.]

WRIEDT, C.

1929. Die Variation der Haustierarten in genetischer Beleuchtung Ztschr. Tierz. u. Züchtungs-Biol. 14:399-413.

WRIEDT, C., and O. L. MoHr.

1928. Amputated, a recessive lethal in cattle, with a discussion on the bearing of lethal factors on the principles of livestock breeding. Jour. Genetics 20: 187-216.

WRIGHT, S.

1918. On the nature of size factors. Genetics $3: 367-74$.

1932. General, group and special size factors. Genetics 17:603-20.

ZaITSCheK, A.

1908. Über die Verteilung des Lebendgewichtes auf die Organe beim Huhn. Landw. Jahrb. 37:150-71. [Cited by Latimer and Pedersen, 1923.]

ZorN, W., and H. F. KRALLINGER.

1934. Die Legeleistung von Bastarden zwischen weissen, einfachkammigen Leghorns und Lachs-hühnern. Arch. Gefl. 8:233-50. 